\title{
Nanoparticles and microbial metabolites as promising resources in anti-inflammatory nanomedicine and biomedicine
}

\author{
Fatemeh Salimi ${ }^{1}$ and Fatemeh Mohammadipanah ${ }^{2}$ \\ ${ }^{1}$ Damghan University \\ ${ }^{2}$ University of Tehran
}

July 28, 2020

\begin{abstract}
Inflammation is a complex pathophysiological process associated with atherosclerosis, cancers, diabetes, osteoporosis, rheumatoid arthritis, cardiovascular and autoimmune diseases. In this review, we represent an overview of microbial-derived compounds, and nanomaterial with anti-inflammatory activity and compare their efficiency, mode actions, and limitations. This paper aims to provide an insight on possible approaches to expand the chemical space of anti-inflammatory drugs. The micro-based approach through the discovery of new anti-inflammatory compounds from microorganisms and nano-based approach through the augmentation by nanomaterials are among the main suggested natural and chemical resources to provide new anti-inflammation drugs in the future. Furthermore, some nanomaterials by improving the anti-inflammatory properties of commercial drugs or microbial compounds through enhancing their solubility, decreasing unfavorable effects, donating excellent targeting, allowing a lower dosage, and providing substitute less-invasive delivery routes, have shown their indirect anti-inflammatory activity. Additionally, the efficiency of existing drugs can also be modulated by using new synergistic anti-inflammatory compounds from microorganisms or modification/augmentation by nanomaterials. This will aid in designing new nano and bio-based medications for the prevention and treatment of numerous inflammation related-debilitating diseases.
\end{abstract}

\begin{abstract}
Inflammation is a complex pathophysiological process associated with atherosclerosis, cancers, diabetes, osteoporosis, rheumatoid arthritis, cardiovascular and autoimmune diseases. In this review, we represent an overview of microbial-derived compounds, and nanomaterial with anti-inflammatory activity and compare their efficiency, mode actions, and limitations. This paper aims to provide an insight on possible approaches to expand the chemical space of anti-inflammatory drugs. The micro-based approach through the discovery of new anti-inflammatory compounds from microorganisms and nano-based approach through the augmentation by nanomaterials are among the main suggested natural and chemical resources to provide new antiinflammation drugs in the future. Furthermore, some nanomaterials by improving the anti-inflammatory properties of commercial drugs or microbial compounds through enhancing their solubility, decreasing unfavorable effects, donating excellent targeting, allowing a lower dosage, and providing substitute less-invasive delivery routes, have shown their indirect anti-inflammatory activity. Additionally, the efficiency of existing drugs can also be modulated by using new synergistic anti-inflammatory compounds from microorganisms or modification/augmentation by nanomaterials. This will aid in designing new nano and bio-based medications for the prevention and treatment of numerous inflammation related-debilitating diseases.
\end{abstract}

KEYWORDS: Inflammation; Anti-inflammation drugs; Microbial metabolites; Nanomaterial; Drug development; Green chemistry

\section{INFLAMMATION PHENOMENON}


Disrupted tissue homeostasis due to infection or physico-chemical tissue damage promotes inflammation as a pervasive form of host defense, which involves the innate and adaptive immune systems by rapidly destroying or isolating the source of the disturbance usually resulted in restoring tissue homeostasis (Medzhitov, 2008; Soehnlein \& Lindbom, 2010). Collateral damage to the tissues is unavoidable in inflammation due to the destructive characteristic of inflammation substances to both causing agents and hosts (Wynn, 2004).

The molecular patterns of pathogens are identified via the innate immune system like intracellular nucleotidebinding domain, Toll-like receptors (TLRs), and leucine-rich-repeat containing receptors (NOD-like receptors (NLRs)). TLR activates common signaling pathways, which lead to immediate activation of NF- $x \mathrm{~B}$. Activated $\mathrm{NF}-x \mathrm{~B}$ translocates to the nucleus and, by binding to target genes upregulates their expression. NLRs in response to increasing numbers of molecular patterns activate the immune system through transcription and translation of target genes, which result in the inducible expression of pro-inflammatory cytokines like interleukin-1-beta (IL-1 $\beta$ ), IL-6 and tumor necrosis factor (TNF)- $\alpha$. Effector cells, including monocytes and neutrophils, are attracted to the site of the disturbance due to molecules. The activity of these immune cells led to a cytotoxic environment following the release of harmful chemicals, including reactive oxygen species (ROS) and reactive nitrogen species (RNS) and various proteinases from cytoplasmic granules.

The effector functions of inflammation are further arranged via the adaptive immune system, including T-helper (Th) cells, which modulate the inflammation process. Upon exposure of native Th cells to the antigens, they differentiate into several various cells, like Th1, Th2, and Treg cells. The first one, through producing interferon-gamma (IFN- $\gamma$ ), IL-2, and TNF- $\alpha$ with antiviral and immunoregulatory characteristics and activation of macrophage, can act against the intracellular pathogens. The second Th cells (Th2 cells) by releasing IL-4, IL-5, and IL-13 induce macrophage activation, and IgE production and eosinophil maturation (Graham, 2002; Mosmann \& Coffman, 1989).

The third group of Th cells suppresses the activation, proliferation, and effector functions of immune cells including, NK cells, B cells, antigen-presenting cells, and T cells. This is derived by the production of IL-10 and TGF- $\beta$ which lead to the resolution of acute inflammation as the last phase of this defense process once the disturbance is removed. The persistence of disturbance can lead to another form of inflammation, chronic inflammation, in which neutrophils are substituted with macrophages and T cells (Serhan \& Savill, 2005).

\section{Acute and chronic inflammation}

Acute inflammation consists of the non-specific, urgent, and early responses to the adverse stimuli that are swiftly resolved. It is initiated by activation of the present immune cells in the affected tissue, including dendritic cells, macrophages, mast cells, which release mediators upon their activation. The inflammatory mediators have a short lifecycle and are degraded in tissue. Therefore, by removing the disturbance, selective pressure encourages termination of the inflammatory response and tissue repair starts restoring the functionality. The persist of the disturbance leads to chronic inflammation for years (Ashley, Weil, \& Nelson, 2012).

\section{MAIN DRUG TARGETS of THE INFLAMMATION PROCESS}

The major anti-inflammatory targets are the enzymes, COX-1, COX-2, which catalyze the rate-determining process of arachidonic acid conversion to prostanoids. COX activation results in the formation of different prostanoids, including prostaglandins, prostacyclin, or thromboxane, which act as mediators of inflammatory and anaphylactic reactions, vasoconstriction (thromboxane), vasodilation ( prostaglandin I2) and inhibition of platelet activation (prostacyclin). Activation of I $\varkappa \mathrm{B}$ kinase (IKK) complex through LPS or TNF- $\alpha$ leads to liberating cytosolic NF- $\chi \mathrm{B}$ from repression through $\mathrm{I} \varkappa \mathrm{B} \alpha$ ubiquitination and degradation. JNK-AP-1 pathway is activated by these stimuli. Inflammation is propagated by coordinated actions of $\mathrm{NF}-x \mathrm{~B}$ and AP-1 through enhancing transcription of cytokines, chemokines, and other pro-inflammatory genes (Figure $1)$.

Role of inflammation in the initiation of life-threatening diseases 
The short term under control inflammation, acute inflammation, is considered to be beneficial to the detrimental agent while unresolved, persistent inflammation, chronic inflammation, is characterized by the simultaneous destruction and healing of the tissue. Therefore, this type of inflammation can lead to tissue damage, and consequently, several life-threatening diseases such as Alzheimer's disease (AD), rheumatoid arthritis, persistent asthma, atherosclerosis, cardiovascular disease, and cancer (Murakami \& Hirano, 2012).

\section{MICROBIAL DERIVED ANTI-INFLAMMATORY COMPOUNDS}

The microorganisms derived natural products have been considered as one of the most prolific reservoirs of natural therapeutic compounds (F Salimi, Hamedi, Motevaseli, \& Mohammadipanah, 2018). It has been estimated that the hit rate for natural products is 100 -fold higher than the hit rate for synthetic compounds. Microbial natural compounds have unique properties including, structural diversity and complexity in the backbone, ring systems, and functional groups, occupying a unique chemical space (Lam, 2007). They mostly possess the expected pharmacokinetic characteristics which is necessary for clinical development. These natural compounds may target unknown pathological targets and contribute to revealing the detailed pathway of diseases. A large number of commercial drugs (more than 130 drugs) for the treatment of life-threatening diseases like cancers, diabetes, and infections have been originated from microorganisms. Also, more than 60 microbial-derived compounds with proved bioactivity against infections, inflammations, cancers, neurological, metabolic, cardiovascular and immunological disorders are currently in different steps of clinical trials. Microorganisms are the more readily reproducible source of bioactive compounds in comparison to the plants and animals. According to the statics of the microbial-derived commercial drugs, actinomycetes, fungi, and myxobacteria are the richest bioresources of structurally unique and medically important compounds (Harvey, 2008; Reichenbach, Gerth, Irschik, Kunze, \& Höfle, 1988; Fatemeh Salimi, Hamedi, Motevaseli, \& Mohammadipanah, 2019; F Salimi, Jafari-Nodooshan, Zohourian, Kolivand, \& Hamedi, 2018; Schaberle, Lohr, Schmitz, \& Konig, 2014; Vasundhara, Reddy, \& Kumar, 2019; Watve, Tickoo, Jog, \& Bhole, 2001). Many compounds with anti-inflammatory activity have been extracted from microorganisms and an overview of these prodrugs is summarized in Tables 1 and 2.

\section{Limitations in anti-inflammatory drug discovery from microbial resources}

Based on the survey in this paper, the most prevalent type of anti-inflammatory compounds produced by bacteria and fungi belongs to chemical groups of lactones, macrocyclic lactone, macrolactin 9 and 10 membered bis-lactones, lipopeptides, cyclic heptapeptides, bicyclic depsipeptides, norditerpens, merosesquiterpenoids, indole diterpenes, sesquiterpenoids, pyrrol, pyrone, oxopyran, alkaloids, dihydroisocoumarin, dichloroisocoumarins, carbazole, polyketides, and anthracene.

Despite the unprecedented value of natural compounds as an origin of pharmaceutically active compounds, the larger number of pharmaceutical companies have reduced or even ceased their research program on natural products. The dereplication approaches are generally not efficient enough to avoid the rediscovery of known compounds. Although new technologies could enhance the rate of drug discovery, they have not been greatly improved to meet the demands of the industry mainly due to the incompatibility of natural product libraries with the conditions of high-throughput screening. From an industrial point of view, discovering a natural drug with desirable therapeutic activity is a difficult, time, and cost-consuming process. Additionally, obtaining potent or compounds might need strains from marine or extreme habitats that demands a challenging and not always accessible sample collection step (Almasi, Mohammadipanah, Adhami, \& Hamedi, 2018; Heidarian, Mohammadipanah, Maghsoudlou, Dashti, \& Challis, 2019). Also, there are many compounds together with the compound of interest in the crude extracts. The low amount production of active compound another limitation that demand ether intensve purification procedures, production optimization or genetic manipulation. Besides, further quantities of active compounds are essential for preclinical development. Thus, large-scale fermentation is required which substantially affects the timeline of the development. Synthesis or modification of natural compounds via combinatorial chemistry is also not readily possible due to their large size, complexity, and a high number of functional groups.

Although it seems that screening of natural products is being improved through the emergence of new tech- 
nologies including various high-throughput screening methods, genome mining, and innovative approaches in analytical chemistry such as the high-resolution separation technique and efficient detection systems which make it possible to trace compounds and determine the structures at the nanomole scale. In addition, combined or tandem technologies can accelerate the dereplication, isolation and structure elucidation of the effective natural compounds which exist in the crude extracts. Nevertheless, the risk of the rediscovery of known drugs can be minimized by novel sampling methodologies from unusual or extreme habitats or marine environments and screening the new microbial taxa (Exarchou, Fiamegos, van Beek, Nanos, \& Vervoort, 2006; Exarchou et al., 2005; Lam, 2007; Tatsis et al., 2007).

\section{NANOMATERIAL AS ANTI-INFLAMMATORY AGENTS}

Understanding the significance of nanoparticle properties like size, shape and surface characteristics to optimize biological interactions, are creating new dimensions to develop nanoparticles as healing agents. Ultra-small size of nanomaterials, which lead to an exponential enhancement in the surface region, effective stiffness, and high reactivity donate altered physiochemical properties, which cannot be observed in the bulk material with the same composition. Recently, some therapeutic nanomaterials, including nanoparticles, nanopatterned surfaces, nanofibers, nanoporous, scaffolds, and nanotubes have been developed to treat lifethreatening diseases like cancer, diabetes, pain, asthma, allergy, infections (Petros \& DeSimone, 2010; Zhang et al., 2008). The promising therapeutic activity of nanomaterials in the suppression of inflammation has also been reported, and some of the nanomaterial derivatives has presented with anti-inflammation activity in Table 3 and 4.

\section{Mechanism of action of nanomaterial with anti-inflammatory activities}

Anti-inflammatory activities of nanomaterials can be divided into indirect and direct mechanisms (Ilinskaya \& Dobrovolskaia, 2014). Among the indirect anti-inflammatory activities of nanomaterials can be their ability to carry anti-inflammatory drugs to provide targeted delivery and controlled release (Cooper \& Harirforoosh, 2014). Nanomaterials including liposomes, dendrimers, polymeric nanoparticle (NP), lipid NP, chitosan NP, dendrimer-like polymers are reported as successful carriers of agents with anti-inflammatory activities like corticosteroids, indomethacin, methotrexate, receptor's antagonists, siRNA against cytokines and signaling molecules, siRNA against C-C chemokine receptor type 2 (CCR2) and selectins' antagonists. In addition, these delivery agents can increase the solubility and half-life of imperfectly water-soluble drugs, extend the half-life of systemic drug circulation via minimizing immunogenicity and the frequency of administration through releasing drugs at a sustained rate or in an environmentally responsible procedure and alleviate systemic side effects through drug delivery in a targeted manner. Nanomaterials via reducing particle size up to nanosize and encapsulating the drug in to water-soluble polymer enhance solubility and bioavailability of drugs. Nanomaterials also can simultaneously deliver more than one drug (Ilinskaya \& Dobrovolskaia, 2014).

In addition to indirect anti-inflammatory activities of nanomaterials, they can directly reduce the inflammation process when they act as anti-cytokines. They can exhibit anti-cytokines either through the reduction of cytokine gene expression or preventing interaction among cytokine and its receptor-like gold NP. Nanomaterial can also illustrate the anti-selectin activity which blocks extravasation of leukocytes across the endothelial barrier affected regions such as dendritic polyglycerol sulfates or antioxidants like cerium oxide NP, gold NP, fullerene derivate. The nanomaterial structures that their anti-inflammatory activity is revealed so far are presented in Tables 3 and 4, respectively.

\section{Limitation in applications of nanomaterial derived anti-inflammatory agents}

Development of nanomaterials with anti-inflammatory effects to drugs is currently confronting their production by their probable systematic toxic effect because of their very high reactivity, going through blood-brain barrier, generating reactive oxygen species, imposing adverse effects on cell organelles, accumulating or disintegrating in the body as the major existing challenges. Different types of nanoparticles can be synthesized using various physical, chemical, and biological approaches (De Jong \& Borm, 2008; Shubhika, 2013). Due to the ability of physical and chemical methods to produce high quantities of nanoparticles with a unified 
size and shape in a relatively short time, these methods are more prevalent than the biological methods. Nevertheless, physically and chemically synthesis of nanoparticles are complicated and lead to the production of hazardous toxic wastes which are harmful to human and ecosystems (Gan, Ng, Huang, \& Li, 2012). Such disadvantages of physical and chemical methods confine the application of physically and chemically synthesized nanoparticles, especially in their biomedical applications.

Consequently, biological or hybrid strategies can be considered as green, nontoxic, cost-effective and ecofriendly alternatives owning to the elimination of consuming toxic chemicals and reduction of energy consumption (Parveen, Banse, \& Ledwani, 2016). Metallic nanoparticles with specific properties like higher catalytic reactivity and a greater specific surface area can be biosynthesized in a biogenic enzymatic process using metal resistant microorganisms such as bacteria (e.g., actinomycetes), fungi and yeasts which are readily cultivable in labs and possess various intracellular and extracellular enzymes $(\mathrm{Li}, \mathrm{Xu}, \mathrm{Chen}, \&$ Chen, 2011). Despite considerable advantages of bio-based synthesis of nanoparticles, limited control on the size, shape and distribution of nanoparticles, time-consuming process of production and cost-intensive down streaming processing are major challenges of nanoparticle biosynthesis, which should be addressed to evolve it as an economically profitable method for large-scale production of nanoparticles.

\section{COMPARING ANTI-INFLAMMATORY MODE ACTION OF MICROBIAL AND NANO- MATERIAL DERIVED COMPOUNDS}

The current commercial anti-inflammatory drugs are the steroidal and the non-steroidal agents with their side effects such as the increased risk of liver cancer, cardiomyopathy, blood pressure, heart attack, stroke, gastrointestinal complications, and infertility. Therefore, development of novel anti-inflammatory drugs is vital to ensure the prevention of some systemic and metabolic disease which are associated or triggered with the chronic inflammation. Accordingly, the secondary metabolites from microorganisms from diverse chemical classes, including alkaloids, steroids, terpenoids, polyphenolics, phenylpropanoids, fatty acids, and lipids have been screened for the development of drugs with anti-inflammatory effects through various mechanisms such as reduction of TNF- $\alpha$ levels, attenuation of cyclooxygenase (COX)-2 activity, inhibition of TNF- $\alpha$ and nitric oxide synthase (NOS), interleukins formation and NF- $x \mathrm{~B}$ translocation to the nucleus. In addition, the anti-inflammatory activity of various nano-materials with various mode actions, including anti-cytokine, antiadhesive, antioxidant activities and inhibiting COX has also been revealed. These nanomaterials are likely to become nanotechnology-derived pharmaceuticals in the future.

Overall, the chemical diversity of the anti-inflammatory compounds described from microbial sources so far is observed higher than nanomaterials. The common mechanism of action between microbial and nanomaterial sources includes anti-TNF- $\alpha$ and INF- $\gamma$ activity, inhibitory effect on IL-1, IL-6 and nitric oxide synthase expression and NF- $x \mathrm{~B}$, Cox-2 and T-helper activities. Some anti-inflammatory activities like inhibitory effect on IL-5, IL-13, ICAM-1 and PTP1B expression, PGE2 release, and increasing TGF- $\beta$ production are just reported from microbial derived compounds with anti-inflammatory activities.

On the other hand, some anti-inflammatory mode action including inhibiting expression of IL-8 and generation of anaphylatoxin C5a, blocking $\mathrm{P}$ and L selectins on leukocytes and endothelial cells, preventing degranulation of mast cells, decreasing the infiltration of neutrophils and macrophages as well as increasing expression of anti-inflammatory products such as mannose receptor C-type 1. Although these reported mode

actions extensively depend on the applied bioassays in corresponding studies and extensive investigations are needed to achieve comprehensive comparison among microbial and nanomaterial derived compounds.

\section{DECLARATION OF INTEREST}

Authors declare no conflict of the interest for the content of the paper

\section{FUNDING SOURCES}

No fund used to support the research of the manuscript.

\section{REFERENCES}


Abd-Elnaby, H., Abo-Elala, G., Abdel-Raouf, U., Abd-elwahab, A., \& Hamed, M. (2016). Antibacterial and anticancer activity of marine Streptomyces parvus: optimization and application. Biotechnology $\mathcal{E}$ Biotechnological Equipment, 30 (1), 180-191.

Almasi, F., Mohammadipanah, F., Adhami, H. R., \& Hamedi, J. (2018). Introduction of marine-derived Streptomyces sp. UTMC 1334 as a source of pyrrole derivatives with anti-acetylcholinesterase activity. Journal of applied microbiology, 125 (5), 1370-1382.

Ashley, N. T., Weil, Z. M., \& Nelson, R. J. (2012). Inflammation: mechanisms, costs, and natural variation.Annual Review of Ecology, Evolution, and Systematics, 43 , 385-406.

Breyner, N. M., Michon, C., De Sousa, C. S., Vilas Boas, P. B., Chain, F., Azevedo, V. A., . . . Chatel, J. M. (2017). Microbial anti-inflammatory molecule (MAM) from Faecalibacterium prausnitzii shows a protective effect on DNBS and DSS-induced colitis model in mice through inhibition of NF- $\chi \mathrm{B}$ pathway. Frontiers in microbiology, $8,114$.

Brioschi, A., Zara, G. P., Calderoni, S., Gasco, M. R., \& Mauro, A. (2008). Cholesterylbutyrate solid lipid nanoparticles as a butyric acid prodrug. Molecules, 13 (2), 230-254.

Carrillo, C., Teruel, J. A., Aranda, F. J., \& Ortiz, A. (2003). Molecular mechanism of membrane permeabilization by the peptide antibiotic surfactin. Biochimica et Biophysica Acta (BBA)-Biomembranes, 1611 (1), 91-97.

Chauhan, A. S., Diwan, P. V., Jain, N. K., \& Tomalia, D. A. (2009). Unexpected in vivo anti-inflammatory activity observed for simple, surface functionalized poly (amidoamine) dendrimers. Biomacromolecules, 10 (5), 1195-1202.

Chen, C. J., Zhou, Y. Q., Liu, X. X., Zhang, W. J., Hu, S. S., Lin, L. P., . . . Ge, H. M. (2015). Antimicrobial and anti-inflammatory compounds from a marine fungus Pleosporales sp. Tetrahedron letters, 56 (45), 6183-6189.

Chen, S., Liu, Z., Liu, H., Long, Y., Chen, D., Lu, Y., \& She, Z. (2017). Lasiodiplactone A, a novel lactone from the mangrove endophytic fungus Lasiodiplodia theobromae ZJ-HQ1. Organic $\& 3$ biomolecular chemistry, 15 (30), 6338-6341.

Chen, Y., Liu, Z., Liu, H., Pan, Y., Li, J., Liu, L., \& She, Z. (2018). Dichloroisocoumarins with Potential Anti-Inflammatory Activity from the Mangrove Endophytic Fungus Ascomycota sp. CYSK-4. Marine drugs, $16(2), 54$.

Cooper, D. L., \& Harirforoosh, S. (2014). Design and optimization of PLGA-based diclofenac loaded nanoparticles. PloS one, 9 (1), e87326.

Cosseau, C., Devine, D. A., Dullaghan, E., Gardy, J. L., Chikatamarla, A., Gellatly, S., . . . Tagg, J. (2008). The commensal Streptococcus salivarius K12 downregulates the innate immune responses of human epithelial cells and promotes host-microbe homeostasis. Infection and immunity, 76 (9), 4163-4175.

De Jong, W. H., \& Borm, P. J. (2008). Drug delivery and nanoparticles: applications and hazards.International journal of nanomedicine, 3 (2), 133.

Dernedde, J., Rausch, A., Weinhart, M., Enders, S., Tauber, R., Licha, K., . . . Haag, R. (2010). Dendritic polyglycerol sulfates as multivalent inhibitors of inflammation.Proceedings of the National Academy of Sciences, 107 (46), 19679-19684.

Dianzani, C., Cavalli, R., Zara, G. P., Gallicchio, M., Lombardi, G., Gasco, M. R., . . . Fantozzi, R. (2006). Cholesteryl butyrate solid lipid nanoparticles inhibit adhesion of human neutrophils to endothelial cells. British journal of pharmacology, 148 (5), 648-656.

Exarchou, V., Fiamegos, Y. C., van Beek, T. A., Nanos, C., \& Vervoort, J. (2006). Hyphenated chromatographic techniques for the rapid screening and identification of antioxidants in methanolic extracts of 
pharmaceutically used plants. Journal of Chromatography A, 1112 (1-2), 293-302.

Exarchou, V., Krucker, M., van Beek, T. A., Vervoort, J., Gerothanassis, I. P., \& Albert, K. (2005). LCNMR coupling technology: recent advancements and applications in natural products analysis. Magnetic Resonance in Chemistry, 43 (9), 681-687.

Gan, P. P., Ng, S. H., Huang, Y., \& Li, S. F. Y. (2012). Green synthesis of gold nanoparticles using palm oil mill effluent (POME): a low-cost and eco-friendly viable approach.Bioresource technology, 113 , 132-135.

Gomathi, A., \& Gothandam, K. M. (2019). Investigation of anti-inflammatory and toxicity effects of mangrove-derived Streptomyces rochei strain VITGAP173. Journal of cellular biochemistry, 120 (10), 1708017097.

Graham, A. L. (2002). When T-helper cells don't help: immunopathology during concomitant infection. The Quarterly Review of Biology, 77 (4), 409-434.

Gupta, U., Agashe, H. B., \& Jain, N. K. (2007). Polypropylene imine dendrimer mediated solubility enhancement: effect of $\mathrm{pH}$ and functional groups of hydrophobes. J Pharm Pharm Sci, 10 (3), 358-367.

Harvey, A. L. (2008). Natural products in drug discovery. Drug discovery today, 13 (19-20), 894-901.

Hassan, H. M., Boonlarppradab, C., \& Fenical, W. (2016). Actinoquinolines A and B, anti-inflammatory quinoline alkaloids from a marine-derived Streptomyces sp., strain CNP975. The Journal of antibiotics, 69 (7), 511.

Hayder, M., Fruchon, S., Fournié, J.-J., Poupot, M., \& Poupot, R. (2011). Anti-inflammatory properties of dendrimers per se. The Scientific World Journal, 11 , 1367-1382.

Heidarian, S., Mohammadipanah, F., Maghsoudlou, A., Dashti, Y., \& Challis, G. L. (2019). Anti-microfouling activity of Glycomyces sediminimaris UTMC 2460 on dominant fouling bacteria of Iran marine habitats. Frontiers in microbiology, $9,3148$.

Hirst, S. M., Karakoti, A. S., Tyler, R. D., Sriranganathan, N., Seal, S., \& Reilly, C. M. (2009). Antiinflammatory properties of cerium oxide nanoparticles. Small, 5 (24), 2848-2856.

Howard, K. A., Paludan, S. R., Behlke, M. A., Besenbacher, F., Deleuran, B., \& Kjems, J. (2009). Chitosan/siRNA nanoparticle-mediated TNF- $\alpha$ knockdown in peritoneal macrophages for anti-inflammatory treatment in a murine arthritis model.Molecular therapy, 17 (1), 162-168.

Hu, J.-B., Kang, X.-Q., Liang, J., Wang, X.-J., Xu, X.-L., Yang, P., . . . Du, Y.-Z. (2017). E-selectintargeted sialic acid-PEG-dexamethasone micelles for enhanced anti-inflammatory efficacy for acute kidney injury. Theranostics, 7 (8), 2204.

Ilinskaya, A., \& Dobrovolskaia, M. (2014). Immunosuppressive and anti-inflammatory properties of engineered nanomaterials. British journal of pharmacology, 171 (17), 3988-4000.

Itoh, J., OMOTO, S., SHOMURA, T., NISHIZAWA, N., MIYADO, S., YUDA, Y., . . . INOUYE, S. (1981). Amicoumacin-A, a new antibiotic with strong antiinflammatory and antiulcer activity. The Journal of antibiotics, 34 (5), 611-613.

Jensen, P. R., Moore, B. S., \& Fenical, W. (2015). The marine actinomycete genus Salinispora: a model organism for secondary metabolite discovery. Natural product reports, 32 (5), 738-751.

Kim, D.-C., Quang, T. H., Ngan, N. T. T., Yoon, C.-S., Sohn, J. H., Yim, J. H., . . . Oh, H. (2015). Dihydroisocoumarin derivatives from marine-derived fungal isolates and their anti-inflammatory effects in lipopolysaccharide-induced BV2 microglia. Journal of natural products, 78 (12), 2948-2955.

Kim, G., Piao, C., Oh, J., \& Lee, M. (2018). Self-assembled polymeric micelles for combined delivery of anti-inflammatory gene and drug to the lungs by inhalation.Nanoscale, 10 (18), 8503-8514. 
Kim, K.-S., Cui, X., Lee, D.-S., Sohn, J. H., Yim, J. H., Kim, Y.-C., \& Oh, H. (2013). Anti-inflammatory effect of neoechinulin A from the marine fungus Eurotium sp. SF-5989 through the suppression of NF-кB and p38 MAPK pathways in lipopolysaccharide-stimulated RAW264. 7 macrophages. Molecules, 18 (11), 13245-13259.

Kim, S.-D., Cho, J.-Y., Park, H.-J., Lim, C.-R., Lim, J.-H., Yun, H.-I., . . Rhee, M.-H. (2006). A comparison of the anti-inflammatory activity of surfactin A, B, C, and D from Bacillus subtilis. Journal of Microbiology and Biotechnology, 16 (10), 1656-1659.

Kumar, R., Singh, A., Garg, N., \& Siril, P. F. (2018). Solid lipid nanoparticles for the controlled delivery of poorly water soluble non-steroidal anti-inflammatory drugs. Ultrasonics sonochemistry, 40 , 686-696.

Lam, K. S. (2007). New aspects of natural products in drug discovery. Trends in microbiology, 15 (6), 279-289.

Lee, D.-S., Jang, J.-H., Ko, W., Kim, K.-S., Sohn, J. H., Kang, M.-S., . . Oh, H. (2013). PTP1B inhibitory and anti-inflammatory effects of secondary metabolites isolated from the marine-derived fungus Penicillium sp. JF-55. Marine drugs, 11 (4), 1409-1426.

Lee, D.-S., Ko, W., Quang, T. H., Kim, K.-S., Sohn, J. H., Jang, J.-H., . . Oh, H. (2013). Penicillinolide A: a new anti-inflammatory metabolite from the marine fungus Penicillium sp. SF-5292. Marine drugs, 11 (11), 4510-4526.

Lee, H.-S., An, B.-J., Kim, H. J., Cho, Y. H., Kim, D. I., Jang, J. Y., . . Lee, J. S. (2015). Anti-Inflammatory Effect of Violapyrones B and C from a Marine-derived Streptomyces sp. Natural Product Sciences, 21 (4), 251-254.

Lee, S. J., Kim, H. P., Park, B. K., Ahn, S. C., Lee, H. S., \& Ahn, J. S. (1997). Topical anti-inflammatory activity of dianemycin isolated fromStreptomyces sp. MT 2705-4.Archives of pharmacal research, 20 (4), 372 .

Leuschner, F., Dutta, P., Gorbatov, R., Novobrantseva, T. I., Donahoe, J. S., Courties, G., . . Marinelli, B. (2011). Therapeutic siRNA silencing in inflammatory monocytes in mice. Nature biotechnology, 29 (11), 1005 .

Li, X., Xu, H., Chen, Z.-S., \& Chen, G. (2011). Biosynthesis of nanoparticles by microorganisms and their applications. Journal of Nanomaterials, 2011.

Manal M. El-Naggar, H. M. A.-E., 2Seham A. Abou-Shousha, 3Usama M. Abdul-Raouf and 1Ahmed E. Abouelwafa. (2016). Production of Anti-Inflammatory Pyrrol Compound from Marine Bacillus baekryungensis AMHSU. World Journal of Fish and Marine Sciences, 8 (2) , 74-84.

McLeay, L., Smith, B., \& Munday-Finch, S. (1999). Tremorgenic mycotoxins paxilline, penitrem and lolitrem $\mathrm{B}$, the non-tremorgenic 31-epilolitrem B and electromyographic activity of the reticulum and rumen of sheep. Research in Veterinary Science, 66 (2), 119-127.

Medzhitov, R. (2008). Origin and physiological roles of inflammation. Nature, 454 (7203), 428.

Menard, S., Candalh, C., Bambou, J., Terpend, K., Cerf-Bensussan, N., \& Heyman, M. (2004). Lactic acid bacteria secrete metabolites retaining anti-inflammatory properties after intestinal transport. Gut, 53 (6), 821-828.

Moore, B. S., Trischman, J. A., Seng, D., Kho, D., Jensen, P. R., \& Fenical, W. (1999). Salinamides, antiinflammatory depsipeptides from a marine streptomycete. The Journal of Organic Chemistry, 64 (4), $1145-1150$.

Mosmann, T. R., \& Coffman, R. (1989). TH1 and TH2 cells: different patterns of lymphokine secretion lead to different functional properties. Annual review of immunology, 7 (1), 145-173. 
Munukka, E., Rintala, A., Toivonen, R., Nylund, M., Yang, B., Takanen, A., . . . Jalkanen, S. (2017). Faecalibacterium prausnitzii treatment improves hepatic health and reduces adipose tissue inflammation in high-fat fed mice. The ISME journal, 11 (7), 1667.

Murakami, M., \& Hirano, T. (2012). The molecular mechanisms of chronic inflammation development.Frontiers in immunology, 3, 323.

Najlah, M., Freeman, S., Attwood, D., \& D'emanuele, A. (2007). In vitro evaluation of dendrimer prodrugs for oral drug delivery. International journal of pharmaceutics, 336 (1), 183-190.

Neibert, K., Gosein, V., Sharma, A., Khan, M., Whitehead, M. A., Maysinger, D., \& Kakkar, A. (2013). "Click" dendrimers as anti-inflammatory agents: with insights into their binding from molecular modeling studies. Molecular pharmaceutics, 10 (6), 2502-2508.

Niu, S., Xie, C.-L., Xia, J.-M., Luo, Z.-H., Shao, Z., \& Yang, X.-W. (2018). New anti-inflammatory guaianes from the Atlantic hydrotherm-derived fungus Graphostroma sp. MCCC 3A00421. Scientific reports, 8 (1), 530 .

Oh, D.-C., Gontang, E. A., Kauffman, C. A., Jensen, P. R., \& Fenical, W. (2008). Salinipyrones and pacificanones, mixed-precursor polyketides from the marine actinomycete Salinispora pacifica. Journal of natural products, 71 (4), 570-575.

Park, J. S., Yang, H. N., Jeon, S. Y., Woo, D. G., Kim, M. S., \& Park, K.-H. (2012). The use of anti-COX2 siRNA coated onto PLGA nanoparticles loading dexamethasone in the treatment of rheumatoid arthritis. Biomaterials, 33 (33), 8600-8612.

Parveen, K., Banse, V., \& Ledwani, L. (2016). Green synthesis of nanoparticles: Their advantages and disadvantages. Paper presented at the AIP Conference Proceedings.

Petros, R. A., \& DeSimone, J. M. (2010). Strategies in the design of nanoparticles for therapeutic applications. Nature reviews Drug discovery, 9 (8), 615.

Phillips, N. C., Thomas, D., Knight, C. G., \& Dingle, J. T. (1979). Liposome-incorporated corticosteroids. II. Therapeutic activity in experimental arthritis. Annals of the rheumatic diseases, 38 (6), 553.

Poupot, M., Griffe, L., Marchand, P., Maraval, A., Rolland, O., Martinet, L., . . Fournié, J.-J. (2006). Design of phosphorylated dendritic architectures to promote human monocyte activation. The FASEB journal, 20 (13), 2339-2351.

Pretsch, A., Nagl, M., Schwendinger, K., Kreiseder, B., Wiederstein, M., Pretsch, D., . . Debbab, A. (2014). Antimicrobial and anti-inflammatory activities of endophytic fungi Talaromyces wortmannii extracts against acne-inducing bacteria.PloS one, 9 (6), e97929.

Reichenbach, H., Gerth, K., Irschik, H., Kunze, B., \& Höfle, G. (1988). Myxobacteria: a source of new antibiotics. Trends in Biotechnology, 6 (6), 115-121.

Rele, S. M., Cui, W., Wang, L., Hou, S., Barr-Zarse, G., Tatton, D., . . Chaikof, E. L. (2005). Dendrimerlike PEO glycopolymers exhibit anti-inflammatory properties. Journal of the American Chemical Society, 127 (29), 10132-10133.

Renner, M. K., Shen, Y.-C., Cheng, X.-C., Jensen, P. R., Frankmoelle, W., Kauffman, C. A., . . Clardy, J. (1999). Cyclomarins A- C, new antiinflammatory cyclic peptides produced by a marine bacterium (Streptomyces sp.). Journal of the American Chemical Society, 121 (49), 11273-11276.

Rosenberg, O., Seiliev, A., Shulga, A. E., Zhuikov, A., \& Volchkov, V. (2017). Prolongation of AntiInflammatory Activity of Glucocorticosteroids Encapsulated in Large Oligolamellar Liposomes in Treatment of Arthritis in Rabbits.International Journal of BioMedicine, 7 (2), 131-134. 
Ryan, J. J., Bateman, H. R., Stover, A., Gomez, G., Norton, S. K., Zhao, W., . . . Kepley, C. L. (2007). Fullerene nanomaterials inhibit the allergic response. The Journal of immunology, 179 (1), 665-672.

Sahlmann, C., \& Strobel, P. (2016). Pathophysiology of inflammation. Nuklearmedizin. Nuclear medicine, 55 (1), $1-6$.

Salimi, F., Hamedi, J., Motevaseli, E., \& Mohammadipanah, F. (2018). Isolation and screening of rare Actinobacteria, a new insight for finding natural products with antivascular calcification activity. Journal of applied microbiology, 124 (1), 254-266.

Salimi, F., Hamedi, J., Motevaseli, E., \& Mohammadipanah, F. (2019). Coexistence of anticoagulant and anti-vascular calcification activities in Kribbella sp. UTMC 267 metabolites. Iranian journal of pharmaceutical research: IJPR, 18 (1), 459.

Salimi, F., Jafari-Nodooshan, S., Zohourian, N., Kolivand, S., \& Hamedi, J. (2018). Simultaneous antidiabetic and anti-vascular calcification activity of Nocardia sp. UTMC 751. Letters in applied microbiology, 66 (2), 110-117.

Schaberle, T. F., Lohr, F., Schmitz, A., \& Konig, G. M. (2014). Antibiotics from myxobacteria. Natural product reports, 31 (7), 953-972.

Scheinman, R. I., Trivedi, R., Vermillion, S., \& Kompella, U. B. (2011). Functionalized STAT1 siRNA nanoparticles regress rheumatoid arthritis in a mouse model.Nanomedicine, 6 (10), 1669-1682.

Schmidt, N., Art, J., Forsch, I., Werner, A., Erkel, G., Jung, M., . . . Pautz, A. (2012). The antiinflammatory fungal compound (S)-curvularin reduces proinflammatory gene expression in an in vivo model of rheumatoid arthritis. Journal of Pharmacology and Experimental Therapeutics, 343 (1), 106-114.

Serhan, C. N., \& Savill, J. (2005). Resolution of inflammation: the beginning programs the end. Nature immunology, 6 (12), 1191.

Shaunak, S., Thomas, S., Gianasi, E., Godwin, A., Jones, E., Teo, I., . . . Patterson, S. (2004). Polyvalent dendrimer glucosamine conjugates prevent scar tissue formation. Nature biotechnology, 22 (8), 977.

Shen, C.-C., Liang, H.-J., Wang, C.-C., Liao, M.-H., \& Jan, T.-R. (2012). Iron oxide nanoparticles suppressed $\mathrm{T}$ helper 1 cell-mediated immunity in a murine model of delayed-type hypersensitivity. International journal of nanomedicine, 7 , 2729.

Shershakova, N., Baraboshkina, E., Andreev, S., Purgina, D., Struchkova, I., Kamyshnikov, O., . . . Khaitov, M. (2016). Anti-inflammatory effect of fullerene C 60 in a mice model of atopic dermatitis. Journal of nanobiotechnology, 14 (1), 8.

Shin, H. J., Pil, G. B., Heo, S.-J., Lee, H.-S., Lee, J. S., Lee, Y.-J., . . . Won, H. S. (2016). Anti-inflammatory activity of tanzawaic acid derivatives from a marine-derived fungus Penicillium steckii 108YD142. Marine drugs, 14 (1), 14.

Shubhika, K. (2013). Nanotechnology and medicine-The upside and the downside. Int. J. Drug Dev. $\mathcal{E}$ Res, 5 (1), 1-10.

Soehnlein, O., \& Lindbom, L. (2010). Phagocyte partnership during the onset and resolution of inflammation. Nature Reviews Immunology, 10 (6), 427.

Stevenson, C., Capper, E., Roshak, A., Marquez, B., Grace, K., Gerwick, W., . . . Marshall, L. (2002). Scytonemin-a marine natural product inhibitor of kinases key in hyperproliferative inflammatory diseases. Inflammation Research, 51 (2), 112-114.

Strangman, W. K. (2007).Anti-inflammatory capabilities of compounds from marine bacteria in a mouse model of allergic inflammation and asthma. UC San Diego, 
Strangman, W. K., Kwon, H. C., Broide, D., Jensen, P. R., \& Fenical, W. (2009). Potent inhibitors of proinflammatory cytokine production produced by a marine-derived bacterium. Journal of medicinal chemistry, 52 (8), 2317-2327.

Taechowisan, T., Chanaphat, S., Ruensamran, W., \& Phutdhawong, W. S. (2012). Anti-inflammatory effect of 3-methylcarbazoles on RAW 264.7 cells stimulated with LPS, polyinosinic-polycytidylic acid and Pam3CSK. Advances in Microbiology, 2 (2), 98.

Tatsis, E. C., Boeren, S., Exarchou, V., Troganis, A. N., Vervoort, J., \& Gerothanassis, I. P. (2007). Identification of the major constituents of Hypericum perforatum by LC/SPE/NMR and/or LC/MS. Phytochemistry, 68 (3), 383-393.

Toledo, T. R., Dejani, N. N., Monnazzi, L. G. S., Kossuga, M. H., Berlinck, R. G., Sette, L. D., \& Medeiros, A. I. (2014). Potent anti-inflammatory activity of pyrenocine A isolated from the marine-derived fungus Penicillium paxilli Ma (G) K.Mediators of inflammation, 2014.

Vasundhara, M., Reddy, M. S., \& Kumar, A. (2019). Secondary Metabolites From Endophytic Fungi and Their Biological Activities. In New and Future Developments in Microbial Biotechnology and Bioengineering (pp. 237-258): Elsevier.

Watve, M. G., Tickoo, R., Jog, M. M., \& Bhole, B. D. (2001). How many antibiotics are produced by the genus Streptomyces? Archives of Microbiology, 176 (5), 386-390.

Wong, C., Bezhaeva, T., Rothuizen, T. C., Metselaar, J. M., de Vries, M. R., Verbeek, F. P., . . . Rabelink, T. J. (2016). Liposomal prednisolone inhibits vascular inflammation and enhances venous outward remodeling in a murine arteriovenous fistula model. Scientific reports, 6 , 30439.

Woraphatphadung, T., Sajomsang, W., Rojanarata, T., Akkaramongkolporn, P., Ngawhirunpat, T., \& Opanasopit, P. (2017). Preparation and characterization of N-benzyl-N, O-succinyl chitosan polymeric micelles for solubilization of poorly soluble non-steroidal anti-inflammatory drugs. Tropical Journal of Pharmaceutical Research, 16 (10), 2349-2357.

Wynn, T. A. (2004). Fibrotic disease and the T H 1/T H 2 paradigm. Nature Reviews Immunology, 4 (8), 583 .

Yang, X., Kang, M.-C., Li, Y., Kim, E.-A., Kang, S.-M., \& Jeon, Y.-J. (2014). Anti-inflammatory activity of questinol isolated from marine-derived fungus Eurotium amstelodami in lipopolysaccharide-stimulated RAW 264.7 macrophages. J. Microbiol. Biotechnol, 24 (10), 1346-1353.

Yang, X., Kang, M.-C., Li, Y., Kim, E.-A., Kang, S.-M., \& Jeon, Y.-J. (2017). Asperflavin, an AntiInflammatory Compound Produced by a Marine-Derived Fungus, Eurotium amstelodami. Molecules, 22 (11), 1823.

Yiyun, C., Na, M., Tongwen, X., Rongqiang, F., Xueyuan, W., Xiaomin, W., \& Longping, W. (2007). Transdermal delivery of nonsteroidal anti-inflammatory drugs mediated by polyamidoamine (PAMAM) dendrimers. Journal of pharmaceutical sciences, 96 (3), 595-602.

Yoncheva, K., Petrov, P., Pencheva, I., \& Konstantinov, S. (2015). Triblock polymeric micelles as carriers for anti-inflammatory drug delivery. Journal of microencapsulation, 32 (3), 224-230.

Zhang, L., Gu, F., Chan, J., Wang, A., Langer, R., \& Farokhzad, O. (2008). Nanoparticles in medicine: therapeutic applications and developments. Clinical pharmacology $\mathscr{E}$ therapeutics, 83 (5), 761-769.

\section{FIGURE LEGEND}

FIGURE 1 Inflammation cascade and involved pathological targets (Murakami \& Hirano, 2012; Sahlmann \& Strobel, 2016)

TABLE 1 The structure and mechanism of anti-inflammatory compounds reported from bacterial sources 


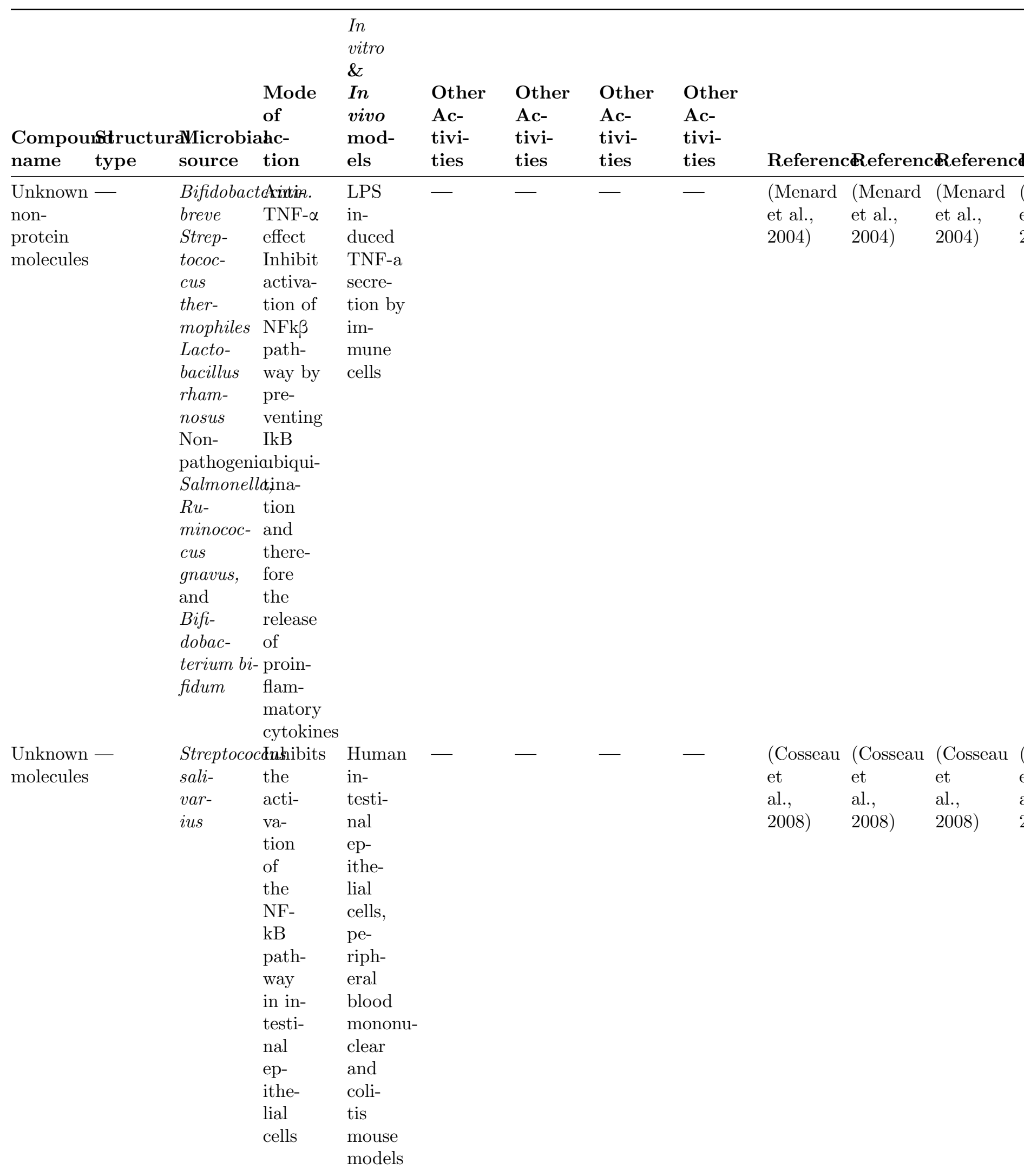




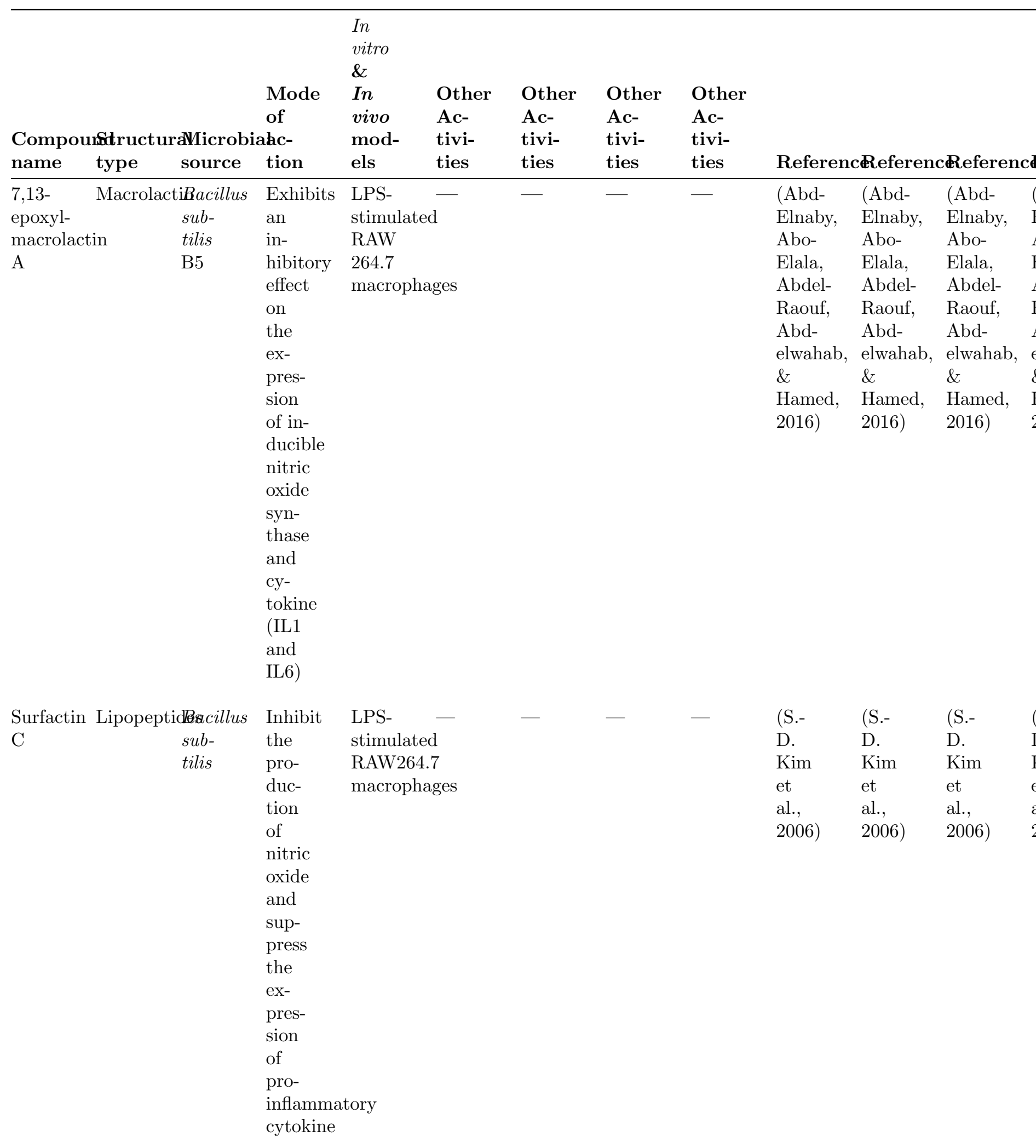




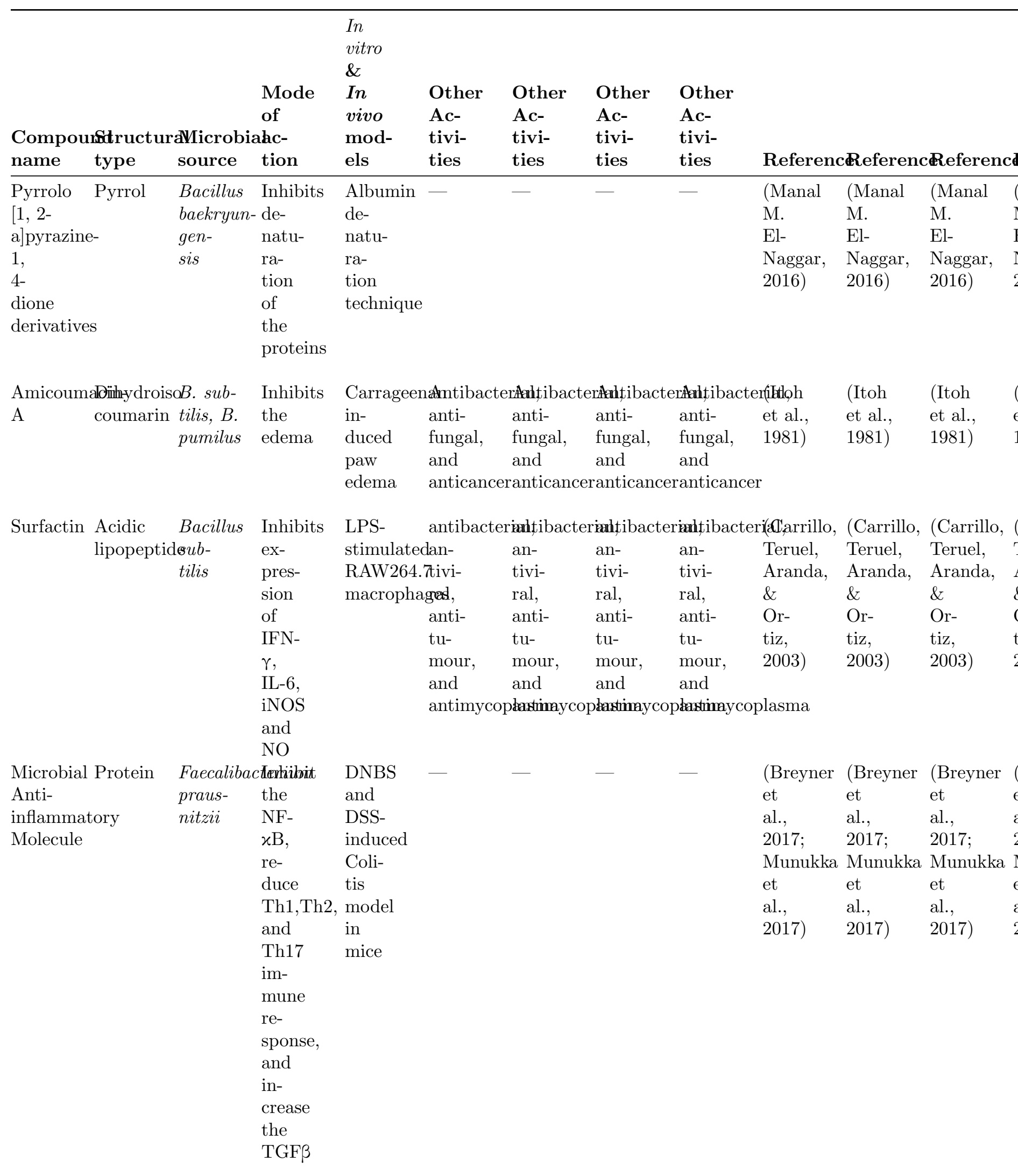




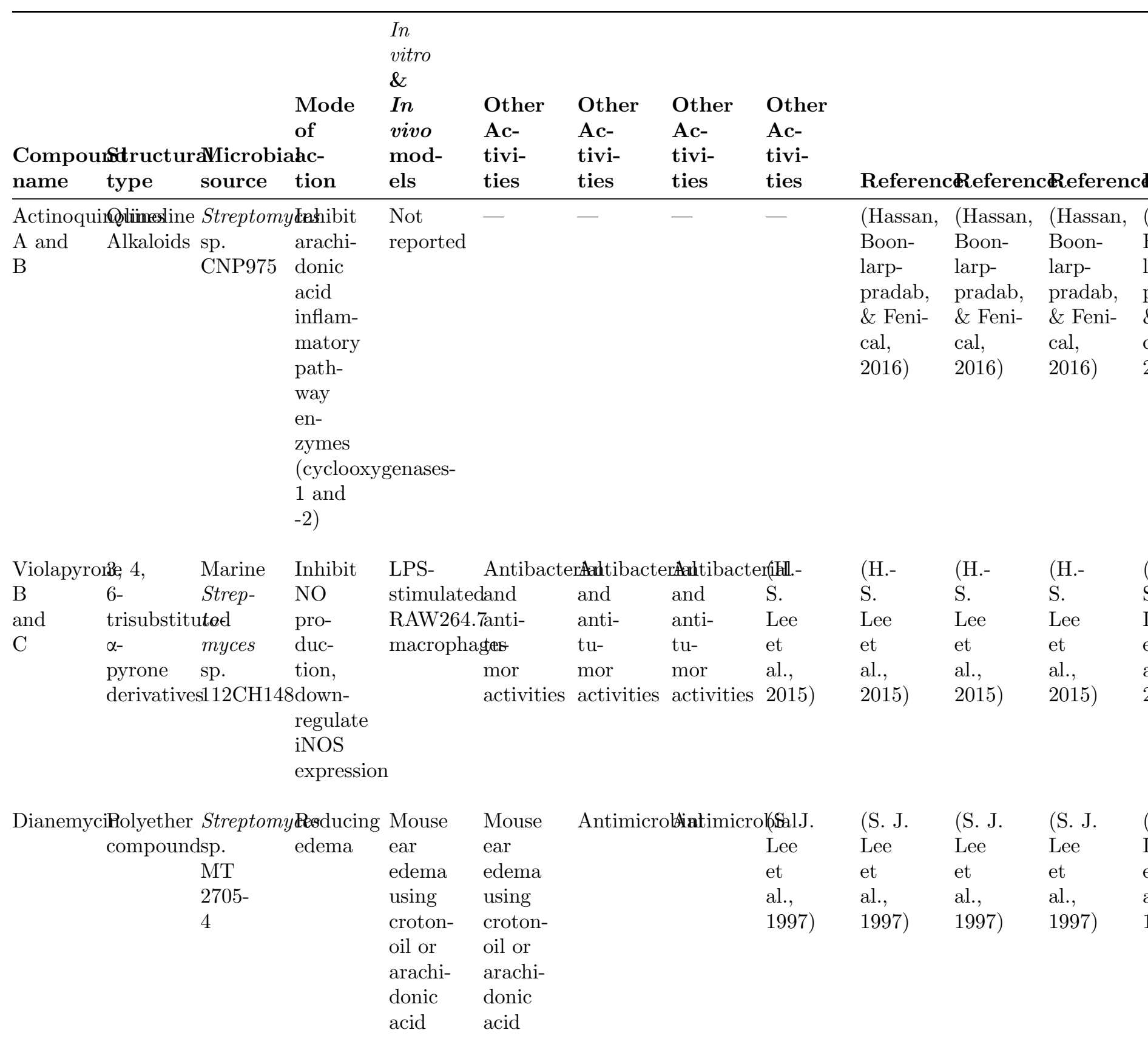




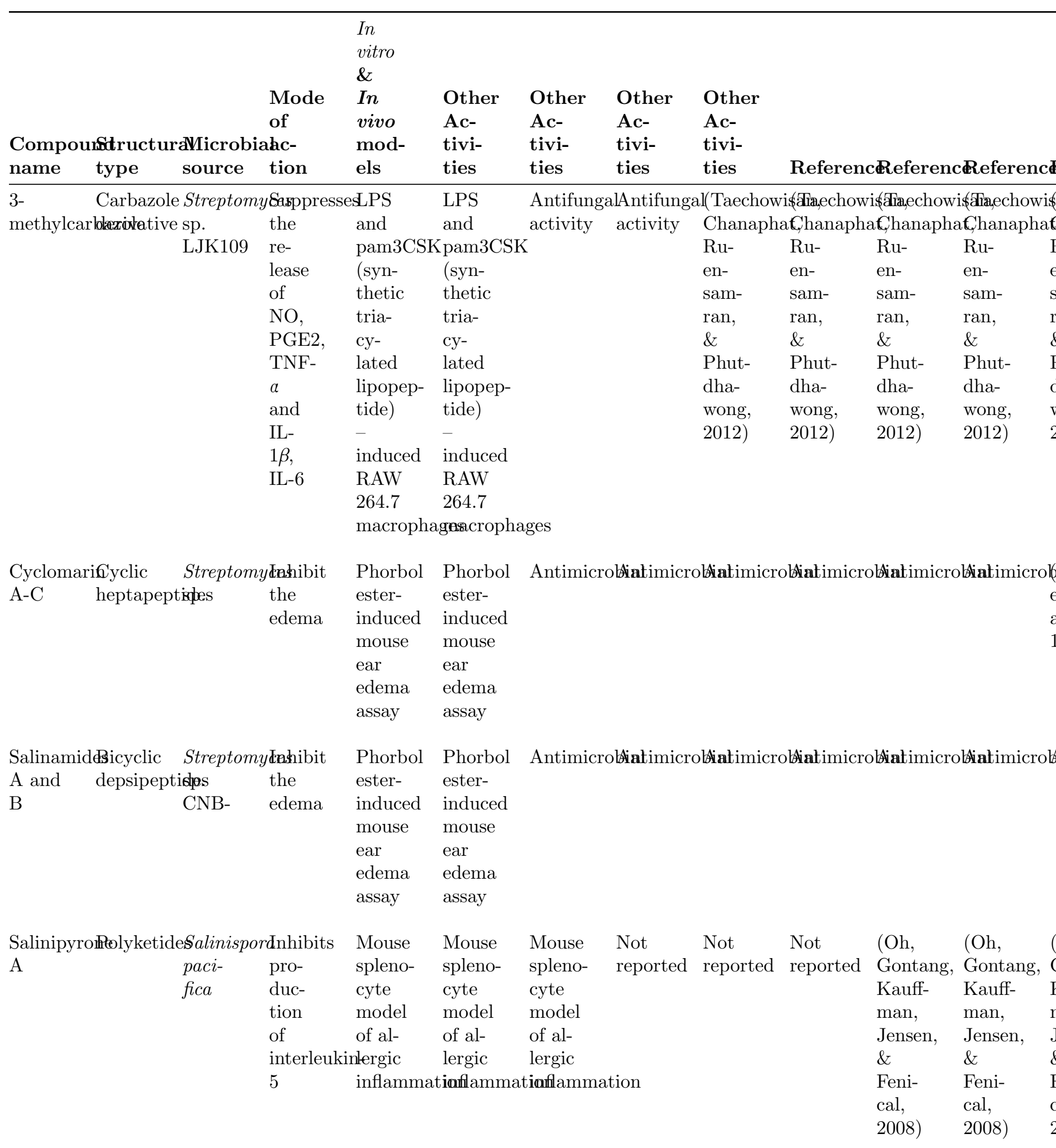




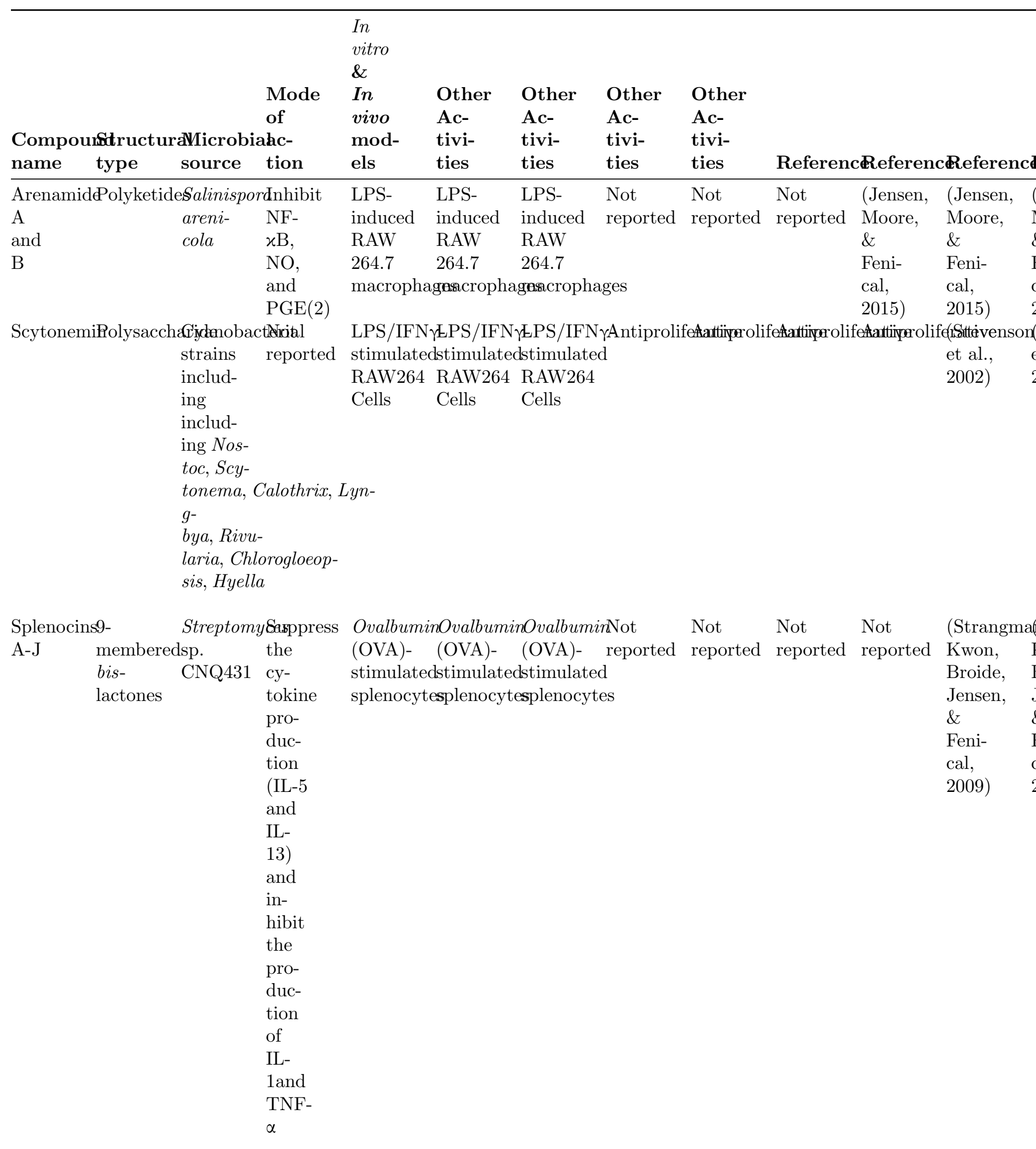




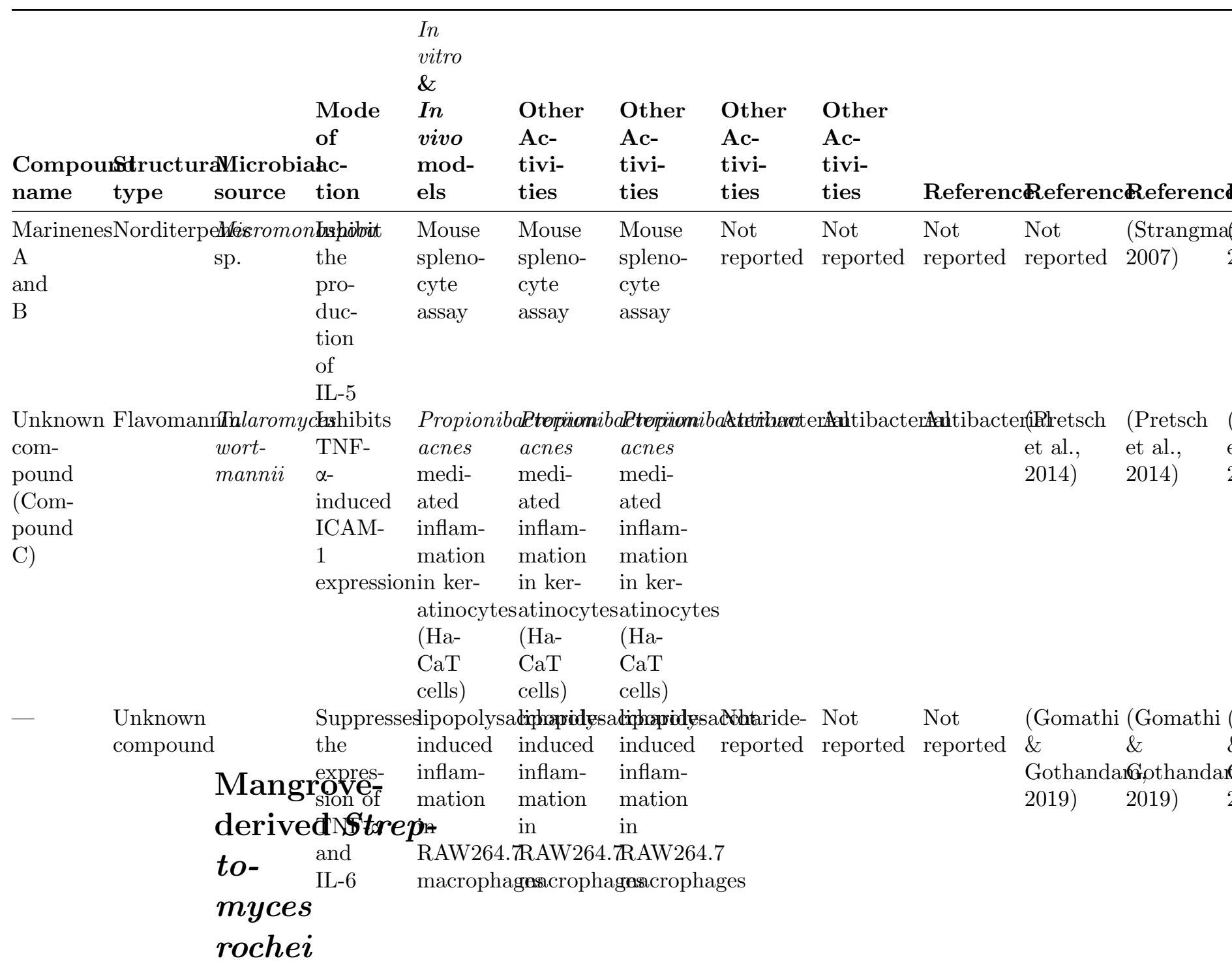

TABLE 2 The structure and mechanism of anti-inflammatory compounds reported from the fungal sources

\begin{tabular}{|c|c|c|c|c|c|c|}
\hline $\begin{array}{l}\text { Compound } \\
\text { name }\end{array}$ & $\begin{array}{l}\text { Structural } \\
\text { type }\end{array}$ & $\begin{array}{l}\text { Microbial } \\
\text { source }\end{array}$ & $\begin{array}{l}\text { Mode of } \\
\text { action }\end{array}$ & $\begin{array}{l}\text { In vitro \& } \\
\text { In vivo } \\
\text { models }\end{array}$ & $\begin{array}{l}\text { Other } \\
\text { Activities }\end{array}$ & Reference \\
\hline $\begin{array}{l}(S)- \\
\text { curvularin }\end{array}$ & $\begin{array}{l}\text { Macrocyclic } \\
\text { lactone }\end{array}$ & $\begin{array}{l}\text { Penicillium } \\
\text { sp. } \\
\text { IBWF3-93 }\end{array}$ & $\begin{array}{l}\text { Reduces the } \\
\text { expression of } \\
\text { proinflam- } \\
\text { matory } \\
\text { cytokines } \\
\text { and } \\
\text { chemokines }\end{array}$ & $\begin{array}{l}\text { Collagen- } \\
\text { induced } \\
\text { arthritis in } \\
\text { mice }\end{array}$ & Not reported & $\begin{array}{l}\text { (Schmidt et } \\
\text { al., 2012) }\end{array}$ \\
\hline
\end{tabular}




\begin{tabular}{|c|c|c|c|c|c|c|}
\hline $\begin{array}{l}\text { Compound } \\
\text { name }\end{array}$ & $\begin{array}{l}\text { Structural } \\
\text { type }\end{array}$ & $\begin{array}{l}\text { Microbial } \\
\text { source }\end{array}$ & $\begin{array}{l}\text { Mode of } \\
\text { action }\end{array}$ & $\begin{array}{l}\text { In vitro \& } \\
\text { In vivo } \\
\text { models }\end{array}$ & $\begin{array}{l}\text { Other } \\
\text { Activities }\end{array}$ & Reference \\
\hline $\begin{array}{l}\text { Pleosporallin } \\
\text { A-C }\end{array}$ & Merosesquiterp & $\begin{array}{l}\text { Ididsesporales } \\
\text { sp. }\end{array}$ & $\begin{array}{l}\text { Inhibits IL-6 } \\
\text { production }\end{array}$ & $\begin{array}{l}\text { LPS-induced } \\
\text { RAW } 264.7 \\
\text { macrophages }\end{array}$ & Not reported & $\begin{array}{l}\text { (C. J. Chen et } \\
\text { al., 2015) }\end{array}$ \\
\hline Penstyrylpyrone & $\begin{array}{l}\text { Styrylpyrone- } \\
\text { type } \\
\text { metabolite }\end{array}$ & $\begin{array}{l}\text { Penicillium } \\
\text { sp. }\end{array}$ & $\begin{array}{l}\text { Inhibits } \\
\text { PTP1B } \\
\text { activity and } \\
\text { reduces NO, } \\
\text { PGE2, } \\
\text { TNF- } \alpha \text { and } \\
\text { IL-1 } \\
\text { production }\end{array}$ & $\begin{array}{l}\text { LPS-induced } \\
\text { RAW } 264.7 \\
\text { macrophages }\end{array}$ & Not reported & $\begin{array}{l}\text { (D.-S. Lee, } \\
\text { Jang, et al., } \\
2013 \text { ) }\end{array}$ \\
\hline $\begin{array}{l}\text { Penicillinolide } \\
\text { A }\end{array}$ & $\begin{array}{l}10- \\
\text { membered } \\
\text { lactone }\end{array}$ & $\begin{array}{l}\text { Penicillium } \\
\text { sp. }\end{array}$ & $\begin{array}{l}\text { Suppresses } \\
\text { production } \\
\text { of pro- } \\
\text { inflammatory } \\
\text { mediators }\end{array}$ & $\begin{array}{l}\text { LPS-induced } \\
\text { RAW } 264.7 \\
\text { macrophages }\end{array}$ & Not reported & $\begin{array}{l}\text { (D.-S. Lee, } \\
\text { Ko, et al., } \\
2013)\end{array}$ \\
\hline $\begin{array}{l}\text { Pyrenocine } \\
\text { A }\end{array}$ & Oxopyran & $\begin{array}{l}\text { Penicillium } \\
\text { paxilli } \\
\mathrm{Ma}(\mathrm{G}) \mathrm{K}\end{array}$ & $\begin{array}{l}\text { Exhibits } \\
\text { anti- } \\
\text { inflammatory } \\
\text { effects on } \\
\text { the } \\
\text { expression of } \\
\text { receptors } \\
\text { directly } \\
\text { related to } \\
\text { cell } \\
\text { migration }\end{array}$ & $\begin{array}{l}\text { LPS-induced } \\
\text { RAW } 264.7 \\
\text { macrophages }\end{array}$ & $\begin{array}{l}\text { Antiantimalarial } \\
\text { and } \\
\text { anticancer }\end{array}$ & $\begin{array}{l}\text { (Toledo et } \\
\text { al., 2014) }\end{array}$ \\
\hline $\begin{array}{l}\text { Tanzawaic } \\
\text { acid Q }\end{array}$ & $\begin{array}{l}\text { Tazawaic acid } \\
\text { derivative }\end{array}$ & $\begin{array}{l}\text { Penicillium } \\
\text { steckii } \\
\text { 108YD142 }\end{array}$ & $\begin{array}{l}\text { Inhibits NOS } \\
\text { and PGE2 } \\
\text { production }\end{array}$ & $\begin{array}{l}\text { LPS-induced } \\
\text { RAW } 264.7 \\
\text { macrophages }\end{array}$ & Not reported & $\begin{array}{l}\text { (Shin et al., } \\
2016 \text { ) }\end{array}$ \\
\hline $\begin{array}{l}\text { Neoechinulin } \\
\text { A }\end{array}$ & Alkaloid & $\begin{array}{l}\text { Eurotium } \\
\text { amstelodami }\end{array}$ & $\begin{array}{l}\text { Suppresses } \\
\text { production of } \\
\text { pro- } \\
\text { inflammatory } \\
\text { mediators, and } \\
\text { cytokines }\end{array}$ & $\begin{array}{l}\text { LPS-induced } \\
\text { RAW } 264.7 \\
\text { macrophages }\end{array}$ & Not reported & $\begin{array}{l}\text { (K.-S. Kim et } \\
\text { al., 2013) }\end{array}$ \\
\hline
\end{tabular}




\begin{tabular}{|c|c|c|c|c|c|c|}
\hline $\begin{array}{l}\text { Compound } \\
\text { name }\end{array}$ & $\begin{array}{l}\text { Structural } \\
\text { type }\end{array}$ & $\begin{array}{l}\text { Microbial } \\
\text { source }\end{array}$ & $\begin{array}{l}\text { Mode of } \\
\text { action }\end{array}$ & $\begin{array}{l}\text { In vitro \& } \\
\text { In vivo } \\
\text { models }\end{array}$ & $\begin{array}{l}\text { Other } \\
\text { Activities }\end{array}$ & Reference \\
\hline Asperflavin & Anthracene & $\begin{array}{l}\text { Eurotium spp. } \\
\text { and } \\
\text { Aspergillus } \\
\text { flavus }\end{array}$ & $\begin{array}{l}\text { Inhibits NO, } \\
\text { PGE2 and } \\
\text { pro- } \\
\text { inflammatory } \\
\text { cytokines, } \\
\text { TNF- } \alpha, \text { IL-1 } \\
\text { and IL-6 } \\
\text { production }\end{array}$ & $\begin{array}{l}\text { LPS- } \\
\text { stimulated } \\
\text { RAW264.7 } \\
\text { macrophages }\end{array}$ & Not reported & $\begin{array}{l}\text { (Yang et al., } \\
2017 \text { ) }\end{array}$ \\
\hline $\begin{array}{l}\text { Lolitrem B } \\
\text { and } 31- \\
\text { epilolitrem } \\
\text { B }\end{array}$ & $\begin{array}{l}\text { Indole } \\
\text { diterpenes }\end{array}$ & $\begin{array}{l}\text { Endophytic } \\
\text { fungus }\end{array}$ & $\begin{array}{l}\text { Inhibit IL-6 } \\
\text { and TNF-a } \\
\text { production }\end{array}$ & $\begin{array}{l}\text { LPS- } \\
\text { stimulated } \\
\text { RAW264.7 } \\
\text { macrophages }\end{array}$ & Not reported & $\begin{array}{l}\text { (McLeay, } \\
\text { Smith, \& } \\
\text { Munday- } \\
\text { Finch, } \\
\text { 1999) }\end{array}$ \\
\hline $\begin{array}{l}\text { Lolitrem B } \\
\text { Desmethyldichlor } \\
\text { Desmethyldichlor } \\
\text { diaportin } \\
\text { Dichlorodiaportin }\end{array}$ & $\begin{array}{l}\text { Lolitrem B } \\
\text { rddïiahlortïstronem } \\
\text { ro- } \\
\text { n }\end{array}$ & $\begin{array}{l}\text { Lolitrem B } \\
\text { arinslophytic } \\
\text { fungus } \\
\text { Ascomycota } \\
\text { sp. CYSK-4 }\end{array}$ & $\begin{array}{l}\text { Lolitrem B } \\
\text { Inhibit NO } \\
\text { production }\end{array}$ & $\begin{array}{l}\text { Lolitrem B } \\
\text { LPS- } \\
\text { stimulated } \\
\text { RAW264.7 } \\
\text { macrophages }\end{array}$ & $\begin{array}{l}\text { Lolitrem B } \\
\text { Antibacterial }\end{array}$ & $\begin{array}{l}\text { Lolitrem B } \\
\text { (Y. Chen et } \\
\text { al., 2018) }\end{array}$ \\
\hline Questinol & $\begin{array}{l}\text { Anthraquinone } \\
\text { derivative }\end{array}$ & $\begin{array}{l}\text { Marine-yerived } \\
\text { Eurotium } \\
\text { amstelodami }\end{array}$ & $\begin{array}{l}\text { Inhibits } \\
\text { production of } \\
\text { NO, PGE2, } \\
\text { COX and } \\
\text { proinflamma- } \\
\text { tory cytokines } \\
\text { including } \\
\text { TNF- } \alpha, \text { IL-1 } \beta \text {, } \\
\text { and IL-6 }\end{array}$ & $\begin{array}{l}\text { LPS- } \\
\text { stimulated } \\
\text { RAW264.7 } \\
\text { macrophages }\end{array}$ & Not reported & $\begin{array}{l}\text { (Yang et al., } \\
2014 \text { ) }\end{array}$ \\
\hline $\begin{array}{l}\text { Dihydroisocouma } \\
\text { Derivatives } \\
(1-6)\end{array}$ & arifactones & $\begin{array}{l}\text { Aspergillus sp. } \\
\text { SF-5974 } \\
\text { Aspergillus sp. } \\
\text { SF-5976 }\end{array}$ & $\begin{array}{l}\text { Inhibit NO } \\
\text { and PGE2 } \\
\text { production by } \\
\text { suppressing } \\
\text { the expression } \\
\text { of iNOS and } \\
\text { COX-2 }\end{array}$ & $\begin{array}{l}\text { LPS- } \\
\text { stimulated } \\
\text { RAW264.7 } \\
\text { macrophages }\end{array}$ & Not reported & $\begin{array}{l}\text { (D.-C. Kim et } \\
\text { al., 2015) }\end{array}$ \\
\hline $\begin{array}{l}\text { Lasiodiplactone } \\
\text { A }\end{array}$ & Lactone & $\begin{array}{l}\text { Lasiodiplodia } \\
\text { theobromae } \\
\text { ZJ-HQ1 }\end{array}$ & $\begin{array}{l}\text { Inhibits NO } \\
\text { production }\end{array}$ & $\begin{array}{l}\text { LPS- } \\
\text { stimulated } \\
\text { RAW264.7 } \\
\text { macrophages }\end{array}$ & Not reported & $\begin{array}{l}\text { (S. Chen et } \\
\text { al., 2017) }\end{array}$ \\
\hline
\end{tabular}




\begin{tabular}{|c|c|c|c|c|c|c|}
\hline $\begin{array}{l}\text { Compound } \\
\text { name }\end{array}$ & $\begin{array}{l}\text { Structural } \\
\text { type }\end{array}$ & $\begin{array}{l}\text { Microbial } \\
\text { source }\end{array}$ & $\begin{array}{l}\text { Mode of } \\
\text { action }\end{array}$ & $\begin{array}{l}\text { In vitro \& } \\
\text { In vivo } \\
\text { models }\end{array}$ & $\begin{array}{l}\text { Other } \\
\text { Activities }\end{array}$ & Reference \\
\hline $\begin{array}{l}\text { Graphostrom } \\
\text { F }\end{array}$ & s Sesquiterpenoids & $\begin{array}{l}\text { Graphostroma } \\
\text { sp. MCCC } \\
3 \mathrm{~A} 00421\end{array}$ & $\begin{array}{l}\text { Inhibits NO } \\
\text { production }\end{array}$ & $\begin{array}{l}\text { LPS- } \\
\text { stimulated } \\
\text { RAW264.7 } \\
\text { macrophages }\end{array}$ & $\begin{array}{l}\text { Antioxidant, } \\
\text { antimalarial, } \\
\text { antinocicep- } \\
\text { tive, } \\
\text { antiemetic, } \\
\text { antitumor, } \\
\text { anti- } \\
\text { inflammatory, } \\
\text { and } \\
\text { antibacterial }\end{array}$ & $\begin{array}{l}\text { (Niu et al., } \\
2018 \text { ) }\end{array}$ \\
\hline
\end{tabular}

TABLE 3 Nanomaterial with reported direct anti-inflammatory activities

\begin{tabular}{|c|c|c|c|c|}
\hline Nanomaterial & Structural type & $\begin{array}{l}\text { Anti- } \\
\text { inflammatory } \\
\text { mechanisms }\end{array}$ & $\begin{array}{l}\text { In vivo or In } \\
\text { vitro assay }\end{array}$ & Reference \\
\hline $\begin{array}{l}1,2- \\
\text { diaminoethane- } \\
\text { cored generation } \\
4.5 \text { generation } \\
\text { poly } \\
\text { (amidoamine) } \\
\text { (PAMAM) } \\
\text { skeleton with } 64 \\
\text { carboxylic acid } \\
\text { surface groups } \\
\text { which nine of } \\
\text { them have been } \\
\text { amido-conjugated } \\
\text { to glucosamine } \\
\text { and glucosamine- } \\
6 \text {-sulfate (Glyco- } \\
\text { Conjugated } \\
\text { PAMAM } \\
\text { Dendrimers) }\end{array}$ & Dendrimers & $\begin{array}{l}\text { Inhibit } \\
\text { chemokines } \\
\text { (macrophage } \\
\text { inhibitory protein } \\
{[\mathrm{MIP}]-1 \alpha \text { and }} \\
\text { IL-8) and } \\
\text { cytokines (TNF- } \alpha \text {, } \\
\text { IL-1 } \beta \text {, and IL-6) } \\
\text { release by } \\
\text { peripheral blood } \\
\text { mononuclear cells }\end{array}$ & $\begin{array}{l}\text { Salmonella } \\
\text { minnesota } \\
\text { LPS-stimulated } \\
\text { immune cells like } \\
\text { monocyte-derived } \\
\text { macrophages and } \\
\text { immature } \\
\text { monocyte-derived } \\
\text { dendritic cells }\end{array}$ & $\begin{array}{l}\text { (Hayder, Fruchon, } \\
\text { Fournié, Poupot, } \\
\text { \& Poupot, 2011; } \\
\text { Shaunak et al., } \\
2004 \text { ) }\end{array}$ \\
\hline $\begin{array}{l}\text { PAMAM } \\
\text { dendrimers with } \\
\text { terminal-NH }{ }_{2} \\
(\mathrm{G} 4-\mathrm{NH} 2),-\mathrm{OH} \\
(\mathrm{G} 4-\mathrm{OH}) \text { and } \\
-\mathrm{COOH} \\
\left(\mathrm{G} 4.5-\mathrm{CO}_{2} \mathrm{H}\right)\end{array}$ & & $\begin{array}{l}\text { Inhibits nitric } \\
\text { oxide synthase } \\
\text { and COX- } 2\end{array}$ & $\begin{array}{l}\text { LPS-induced } \\
\text { peritoneal } \\
\text { macrophages }\end{array}$ & $\begin{array}{l}\text { (Shaunak et al., } \\
2004 \text { ) }\end{array}$ \\
\hline
\end{tabular}




\begin{tabular}{|c|c|c|c|c|}
\hline Nanomaterial & Structural type & $\begin{array}{l}\text { Anti- } \\
\text { inflammatory } \\
\text { mechanisms }\end{array}$ & $\begin{array}{l}\text { In vivo or In } \\
\text { vitro assay }\end{array}$ & Reference \\
\hline $\begin{array}{l}\text { Aminoethylethanolam } \\
\text { capped } \\
\text { dendrimers } \\
(\mathrm{G} 4 \text {-AEEA) and } \\
\text { hydroxyl } \\
\text { terminated } \\
\text { dendrimers } \\
(\mathrm{G} 4-\mathrm{OH})\end{array}$ & & $\begin{array}{l}\text { Inhibitory } \\
\text { activity on } \\
\text { COX-2 }\end{array}$ & $\begin{array}{l}\text { LPS-induced } \\
\text { peritoneal } \\
\text { macrophages }\end{array}$ & $\begin{array}{l}\text { (Chauhan, } \\
\text { Diwan, Jain, \& } \\
\text { Tomalia, 2009) }\end{array}$ \\
\hline $\begin{array}{l}\text { Azabisphosphonate } \\
\text { which is capped } \\
\text { by amino- } \\
\text { bisphosphonate } \\
\text { groups) } \\
\text { dendrimers } \\
\text { (phosphorus- } \\
\text { based } \\
\text { dendrimers) }\end{array}$ & & $\begin{array}{l}\text { Increase the } \\
\text { expression of } \\
\text { anti-inflammatory } \\
\text { products such as } \\
\text { mannose receptor } \\
\text { MRC1 with } \\
\text { reduced levels of } \\
\text { CD64 and CD13 }\end{array}$ & $\begin{array}{l}\text { In vitro cell } \\
\text { culture of human } \\
\text { peripheral blood } \\
\text { mononuclear cells }\end{array}$ & $\begin{array}{l}\text { (Poupot et al., } \\
2006)\end{array}$ \\
\hline $\begin{array}{l}\text { 3- and 4-arm } \\
\text { Polyethylene Oxide } \\
\text { 'stars' and } \\
\text { second-generation } \\
\text { dendrimer on the } \\
\text { N3P3 core } \\
\text { (Polyethylene Oxide } \\
\text { (PEO) Dendrimers) }\end{array}$ & & $\begin{array}{l}\text { Blocking P-and } \\
\text { L-selectins via } \\
\text { sulfate-dependent } \\
\text { interactions and } \\
\text { reduce infiltration } \\
\text { of neutrophils and } \\
\text { macrophages }\end{array}$ & $\begin{array}{l}\text { Mice models of } \\
\text { acute inflammation } \\
\text { which is generated } \\
\text { by intraperitoneal } \\
\text { injection of } \\
\text { thioglycollate }\end{array}$ & (Rele et al., 2005) \\
\hline $\begin{array}{l}\text { Dendritic } \\
\text { polyglycerol } \\
\text { sulfates (dPGS) }\end{array}$ & & $\begin{array}{l}\text { Targets both } \\
\text { L-selectin and } \\
\text { P-selectin on } \\
\text { leukocytes and } \\
\text { endothelial cells, } \\
\text { respectively and } \\
\text { inhibit } \\
\text { anaphylatoxin } \\
\text { C5a generation }\end{array}$ & $\begin{array}{l}\text { Acute allergic } \\
\text { contact dermatitis } \\
\text { mice model }\end{array}$ & $\begin{array}{l}\text { (Dernedde et al., } \\
2010 \text { ) }\end{array}$ \\
\hline $\begin{array}{l}\text { Dendrimers with } \\
\text { terminated } \\
\text { acetylene } \\
\text { (DG0-A, DG1-A } \\
\text { and, DG2-A) and } \\
\text { hydroxyl groups } \\
(\mathrm{OH}) \text { (DG1-OH) }\end{array}$ & & $\begin{array}{l}\text { Inhibit nitric } \\
\text { oxide synthase, } \\
\text { and COX-2 in N9 } \\
\text { microglia cells }\end{array}$ & $\begin{array}{l}\text { LPS-induced } \\
\text { peritoneal } \\
\text { macrophages }\end{array}$ & $\begin{array}{l}\text { (Neibert et al., } \\
2013 \text { ) }\end{array}$ \\
\hline $\begin{array}{l}\text { Cerium oxide } \\
\text { nanoparticles }\end{array}$ & $\begin{array}{l}\text { Metal oxide } \\
\text { nanoparticle }\end{array}$ & $\begin{array}{l}\text { Reduce inducible } \\
\text { NOS amounts at } \\
\text { both mRNA and } \\
\text { protein levels by } \\
\text { the 'reactive sites' } \\
\text { quenching free } \\
\text { radicals }\end{array}$ & & $\begin{array}{l}\text { (Hirst et al., } \\
2009)\end{array}$ \\
\hline
\end{tabular}




\begin{tabular}{|c|c|c|c|c|}
\hline Nanomaterial & Structural type & $\begin{array}{l}\text { Anti- } \\
\text { inflammatory } \\
\text { mechanisms }\end{array}$ & $\begin{array}{l}\text { In vivo or } \text { In } \\
\text { vitro assay }\end{array}$ & Reference \\
\hline $\begin{array}{l}\text { Gold } \\
\text { nanoparticles }\end{array}$ & $\begin{array}{l}\text { Metal } \\
\text { nanoparticle }\end{array}$ & $\begin{array}{l}\text { Anti-cytokine } \\
\text { activity, } \\
\text { anti-TNF- } \alpha \text {, } \\
\text { interfere with } \\
\text { NF- } \chi \mathrm{B} \text {, decrease } \\
\mathrm{I} \varkappa \mathrm{B}-\alpha \text { degradation } \\
\text { and p-Akt }\end{array}$ & $\begin{array}{l}\text { LPS-induced } \\
\text { peritoneal } \\
\text { macrophages }\end{array}$ & $\begin{array}{l}\text { (Ilinskaya \& } \\
\text { Dobrovolskaia, } \\
2014 \text { ) }\end{array}$ \\
\hline Iron oxide & $\begin{array}{l}\text { Metal oxide } \\
\text { nanoparticle }\end{array}$ & $\begin{array}{l}\text { Block activity of } \\
\mathrm{T}_{\text {helper cells and }} \\
\text { macrophages, } \\
\text { inhibit pathways } \\
\text { involved in } \\
\text { cytokine } \\
\text { processing, reduce } \\
\text { expression of } \\
\text { interferon- } \gamma, \text { IL- } 6 \text {, } \\
\text { and TNF- } \alpha \text {, }\end{array}$ & $\begin{array}{l}\text { Stimulated } \\
\text { J774A.1 murine } \\
\text { macrophages }\end{array}$ & $\begin{array}{l}\text { (Shen, Liang, } \\
\text { Wang, Liao, \& } \\
\text { Jan, 2012) }\end{array}$ \\
\hline $\begin{array}{l}\text { Non-modified } \\
\text { fullerene C60 } \\
\text { (N7) }\end{array}$ & Fullerene & $\begin{array}{l}\text { Limit } \\
\text { inflammation of } \\
\text { damaged limb } \\
\text { and promote the } \\
\text { reduction of } \\
\text { leukocyte level }\end{array}$ & $\begin{array}{l}\text { Adjuvant arthritis } \\
\text { in rats }\end{array}$ & (Shen et al., 2012) \\
\hline $\begin{array}{l}\text { The water-soluble } \\
\text { form of fullerene } \\
\text { C60 }\end{array}$ & & $\begin{array}{l}\text { Significantly } \\
\text { suppresses } \\
\text { production of IgE } \\
\text { and Th2, Inhibit } \\
\text { IgE-mediated } \\
\text { histamine release } \\
\text { from peripheral } \\
\text { blood basophils, } \\
\text { suppresses } \\
\text { anaphylaxis }\end{array}$ & $\begin{array}{l}\text { Mouse models of } \\
\text { atopic dermatitis } \\
\text { using subcutaneous } \\
\text { and epicutaneous } \\
\text { applications during } \\
50 \text { days period } \\
\text { Ovalbumin } \\
\text { administrated mice } \\
\text { model }\end{array}$ & $\begin{array}{l}\text { (Shershakova et al., } \\
2016 \text { ) }\end{array}$ \\
\hline $\begin{array}{l}\text { Fullerenol } \\
(\mathrm{C} 60(\mathrm{OH}) \mathrm{n}) \text { and } \\
\text { amino-fullerene } \\
(\mathrm{C} 60(\mathrm{NHCH} 2 \mathrm{CH} 3) \mathrm{n})\end{array}$ & & $\begin{array}{l}\text { Inhibit } \\
\text { IgE-dependent } \\
\text { degranulation of } \\
\text { mast cells and } \\
\text { secretion of } \\
\text { cytokines and } \\
\text { prostaglandins }\end{array}$ & $\begin{array}{l}\text { In vitro culture of } \\
\text { human Mast cells } \\
\text { and peripheral } \\
\text { blood basophils }\end{array}$ & $\begin{array}{l}\text { (Ryan et al., } \\
2007 \text { ) }\end{array}$ \\
\hline
\end{tabular}

TABLE 4 Nanomaterial with indirect anti-inflammatory activities 


\begin{tabular}{|c|c|c|c|c|}
\hline Structural type & Nanomaterial & $\begin{array}{l}\text { Anti- } \\
\text { inflammatory } \\
\text { mechanisms }\end{array}$ & $\begin{array}{l}\text { In vivo or } \text { In } \\
\text { vitro assay }\end{array}$ & Reference \\
\hline \multirow[t]{5}{*}{ Dendrimers } & $\begin{array}{l}\text { G5 Poly } \\
\text { (propylene imine) } \\
\text { loaded by } \\
\text { Indomethacin }\end{array}$ & $\begin{array}{l}\text { Improved } \\
\text { solubility of } \\
\text { Indomethacin }\end{array}$ & HPLC analysis & $\begin{array}{l}\text { (Gupta, Agashe, } \\
\text { \& Jain, 2007) }\end{array}$ \\
\hline & $\begin{array}{l}\text { PAMAM loaded } \\
\text { by Ketoprofen }\end{array}$ & $\begin{array}{l}\text { Improvement of } \\
\text { drug permeation } \\
\text { through the skin }\end{array}$ & $\begin{array}{l}\text { In vitro } \\
\text { permeation } \\
\text { studies with } \\
\text { excised rat skins }\end{array}$ & $\begin{array}{l}\text { (Yiyun et al., } \\
2007 \text { ) }\end{array}$ \\
\hline & $\begin{array}{l}\text { Diflunisal loaded } \\
\text { by PAMAM }\end{array}$ & & & \\
\hline & $\begin{array}{l}\text { G0 PAMAM } \\
\text { loaded by }\end{array}$ & $\begin{array}{l}\text { High permeability } \\
\text { across Caco- } 2\end{array}$ & $\begin{array}{l}\text { Analysis of } \\
\text { transepithelial }\end{array}$ & $\begin{array}{l}\text { (Najlah, Freeman, } \\
\text { Attwood, \& }\end{array}$ \\
\hline & Naproxen & monolayers & $\begin{array}{l}\text { electrical } \\
\text { resistance using a } \\
\text { voltohmmeter }\end{array}$ & $\begin{array}{l}\text { D'emanuele, } \\
2007)\end{array}$ \\
\hline \multirow[t]{3}{*}{ Liposomes } & $\begin{array}{l}\text { Liposomes } \\
\text { containing } \\
\text { cortisol palmitate }\end{array}$ & $\begin{array}{l}\text { Decreases the } \\
\text { joint temperature } \\
\text { of an acute } \\
\text { inflammatory on } \\
\text { an underlying } \\
\text { chronic arthritis }\end{array}$ & $\begin{array}{l}\text { Acute arthritis in } \\
\text { the rabbit knee } \\
\text { by measuring } \\
\text { joint temperature } \\
\text { and diameter }\end{array}$ & $\begin{array}{l}\text { (Phillips, } \\
\text { Thomas, Knight, } \\
\text { \& Dingle, 1979) }\end{array}$ \\
\hline & $\begin{array}{l}\text { Liposomal } \\
\text { prednisolone }\end{array}$ & $\begin{array}{l}\text { Inhibits vascular } \\
\text { inflammation, } \\
\text { reduces } \\
\text { lymphocytes and } \\
\text { granulocytes in } \\
\text { the vascular wall }\end{array}$ & $\begin{array}{l}\text { Murine } \\
\text { arteriovenous } \\
\text { fistula model and } \\
\text { LPS-induced } \\
\text { peritoneal } \\
\text { macrophages }\end{array}$ & $\begin{array}{l}\text { (Wong et al., } \\
2016 \text { ) }\end{array}$ \\
\hline & $\begin{array}{l}\text { Glucocorticosteroids } \\
\text { encapsulated in } \\
\text { large oligolamellar } \\
\text { liposomes }\end{array}$ & $\begin{array}{l}\text { Prolongs the } \\
\text { anti-inflammatory } \\
\text { effect produced } \\
\text { by glucocorticoids }\end{array}$ & $\begin{array}{l}\text { induction of } \\
\text { arthritis in } \\
\text { rabbits by an } \\
\text { intra-articular } \\
\text { administration } \\
\text { into the knee } \\
\text { joint of } \\
\text { poly-D-lysine and } \\
\text { hyaluronic acid }\end{array}$ & $\begin{array}{l}\text { (Rosenberg, } \\
\text { Seiliev, Shulga, } \\
\text { Zhuikov, \& } \\
\text { Volchkov, 2017) }\end{array}$ \\
\hline Micelles & $\begin{array}{l}\text { Dexamethasone- } \\
\text { loaded } \\
\text { E-selectin- } \\
\text { targeting sialic } \\
\text { acid-polyethylene } \\
\text { glycol- } \\
\text { dexamethasone } \\
\text { conjugate micelles }\end{array}$ & $\begin{array}{l}\text { Ameliorate } \\
\text { LPS-induced } \\
\text { production of } \\
\text { pro-inflammatory } \\
\text { cytokines }\end{array}$ & $\begin{array}{l}\text { LPS-activated } \\
\text { human umbilical } \\
\text { vein endothelial } \\
\text { cells }\end{array}$ & (Hu et al., 2017) \\
\hline
\end{tabular}




\begin{tabular}{|c|c|c|c|c|}
\hline Structural type & Nanomaterial & $\begin{array}{l}\text { Anti- } \\
\text { inflammatory } \\
\text { mechanisms }\end{array}$ & $\begin{array}{l}\text { In vivo or In } \\
\text { vitro assay }\end{array}$ & Reference \\
\hline & $\begin{array}{l}\text { Cholesterol- } \\
\text { conjugated } \\
\text { polyamidoamine } \\
\text { micelles loaded by } \\
\text { Resveratrol micelles }\end{array}$ & $\begin{array}{l}\text { Inhibits the nuclear } \\
\text { translocation of } \\
\mathrm{NF}-\varkappa \mathrm{B} \text { and reduced } \\
\text { pro-inflammatory } \\
\text { cytokines in the } \\
\text { lungs A carrier for } \\
\text { combined delivery } \\
\text { of } \\
\text { anti-inflammatory } \\
\text { gene and drug into } \\
\text { the lungs by } \\
\text { inhalation }\end{array}$ & $\begin{array}{l}\text { LPS-activated } \\
\text { macrophage cells } \\
\text { Acute lung injury } \\
\text { (ALI) animal model }\end{array}$ & $\begin{array}{l}\text { (G. Kim, Piao, Oh, } \\
\text { \& Lee, 2018) }\end{array}$ \\
\hline & $\begin{array}{l}\text { Poly(ethylene } \\
\text { oxide)-b-poly(n- } \\
\text { butyl } \\
\text { acrylate)-b- } \\
\text { poly(acrylic acid) } \\
\text { (PEO-PnBA- } \\
\text { PAA) polymeric } \\
\text { micelles loaded by } \\
\text { prednisolone and } \\
\text { budesonide }\end{array}$ & $\begin{array}{l}\text { Exhibit high } \\
\text { colloidal stability, } \\
\text { show a significant } \\
\text { protective effect } \\
\text { against the } \\
\text { cytotoxic damage }\end{array}$ & $\begin{array}{l}\text { Polymeric } \\
\text { micelles as } \\
\text { carriers for } \\
\text { anti-inflammatory } \\
\text { drugs }\end{array}$ & $\begin{array}{l}\text { Yoncheva, } \\
\text { Petrov, Pencheva, } \\
\text { \& Konstantinov, } \\
2015 \text { ) }\end{array}$ \\
\hline & $\begin{array}{l}\text { N-benzyl-N,O- } \\
\text { succinyl chitosan } \\
\text { polymeric micelles }\end{array}$ & $\begin{array}{l}\text { Improves } \\
\text { solubility }\end{array}$ & $\begin{array}{l}\text { Determination of } \\
\text { polymeric micelles } \\
\text { diameter and } \\
\text { surface charge } \\
\text { using Zetasizer } \\
\text { Nano ZS }\end{array}$ & $\begin{array}{l}\text { (Woraphatphadung } \\
\text { et al., 2017) }\end{array}$ \\
\hline $\begin{array}{l}\text { Solid lipid } \\
\text { nanoparticles }\end{array}$ & $\begin{array}{l}\text { Solid lipid } \\
\text { nanoparticles loaded } \\
\text { by ibuprofen, } \\
\text { ketoprofen, } \\
\text { nabumetone }\end{array}$ & $\begin{array}{l}\text { Controls delivery of } \\
\text { poorly water-soluble } \\
\text { non-steroidal } \\
\text { anti-inflammatory } \\
\text { drugs with slow and } \\
\text { sustained drug } \\
\text { release Exhibit } \\
\text { significant efficiency } \\
\text { in drug entrapment }\end{array}$ & $\begin{array}{l}\text { Microprocessor } \\
\text { dissolution test } \\
\text { apparatus }\end{array}$ & $\begin{array}{l}\text { (Kumar, Singh, } \\
\text { Garg, \& Siril, 2018) }\end{array}$ \\
\hline $\begin{array}{l}\text { Polymeric } \\
\text { Nanoparticle }\end{array}$ & $\begin{array}{l}\text { Dexamethasone } \\
\text { loaded polylactic- } \\
\text { co-glycolic acid } \\
\text { nanoparticles } \\
\text { were combined } \\
\text { with siRNA } \\
\text { targeting COX-2 }\end{array}$ & $\begin{array}{l}\text { Co-delivery of } \\
\text { anti-inflammatory } \\
\text { agents suppress } \\
\text { inflammatory } \\
\text { responses }\end{array}$ & $\begin{array}{l}\text { Measuring the } \\
\text { COX-2 and iNOS } \\
\text { in C28/I2 cells } \\
\text { induced by } \\
\text { TNF- } \alpha \text { pre-tto } \\
\text { provoke the } \\
\text { expression of } \\
\text { arthritis-related } \\
\text { molecules i }\end{array}$ & (Park et al., 2012) \\
\hline
\end{tabular}




\begin{tabular}{|c|c|c|c|c|}
\hline Structural type & Nanomaterial & $\begin{array}{l}\text { Anti- } \\
\text { inflammatory } \\
\text { mechanisms }\end{array}$ & $\begin{array}{l}\text { In vivo or In } \\
\text { vitro assay }\end{array}$ & Reference \\
\hline Nanoparticles & $\begin{array}{l}\text { Chitosan } \\
\text { nanoparticles and } \\
\text { cationic liposomes } \\
\text { loaded by siRNA } \\
\text { inhibiting TNF- } \alpha\end{array}$ & $\begin{array}{l}\text { Decreases the } \\
\text { TNF- } \alpha \text { secretion }\end{array}$ & $\begin{array}{l}\text { Mouse model of } \\
\text { collagen-induced } \\
\text { arthritis }\end{array}$ & $\begin{array}{l}\text { (Howard et al., } \\
2009 \text { ) }\end{array}$ \\
\hline Nanoparticles & $\begin{array}{l}\text { Arginine-glycine } \\
\text { aspartic acid-coated } \\
\text { polylactic-co- } \\
\text { glycolic acid } \\
\text { nanoparticles }\end{array}$ & $\begin{array}{l}\text { Targets improved } \\
\text { siRNA uptake in } \\
\text { the paw tissue of } \\
\text { arthritic mice and } \\
\text { increased delivery of } \\
\text { nanoparticles into } \\
\text { lungs Protects } \\
\text { STAT1 siRNA from } \\
\text { degradation by } \\
\text { serum nucleases }\end{array}$ & $\begin{array}{l}\text { Rheumatoid } \\
\text { arthritis in a mouse } \\
\text { model }\end{array}$ & $\begin{array}{l}\text { (Scheinman, } \\
\text { Trivedi, Vermillion, } \\
\text { \& Kompella, 2011) }\end{array}$ \\
\hline $\begin{array}{l}\text { Lipid } \\
\text { nanoparticles }\end{array}$ & $\begin{array}{l}\text { Encapsulated } \\
\text { chemokine } \\
\text { receptor } \\
\text { CCR2-specific } \\
\text { siRNA }\end{array}$ & $\begin{array}{l}\text { Prolongs the } \\
\text { normoglycemic } \\
\text { period }\end{array}$ & $\begin{array}{l}\text { Pancreatic islet } \\
\text { transplantation in } \\
\text { mice with } \\
\text { streptozotocin- } \\
\text { induced } \\
\text { diabetes }\end{array}$ & $\begin{array}{l}\text { (Leuschner et al., } \\
2011 \text { ) }\end{array}$ \\
\hline $\begin{array}{l}\text { Solid lipid } \\
\text { nanoparticles }\end{array}$ & $\begin{array}{l}\text { Cholesteryl } \\
\text { butyrate solid } \\
\text { lipid } \\
\text { nanoparticles }\end{array}$ & $\begin{array}{l}\text { inhibits the } \\
\text { adhesion of } \\
\text { neutrophil } \\
\text { endothelial cells }\end{array}$ & $\begin{array}{l}\text { Adhesion analysis } \\
\text { by quantified } \\
\text { microimaging } \\
\text { fluorescence } \\
\text { analysis }\end{array}$ & $\begin{array}{l}\text { (Brioschi, Zara, } \\
\text { Calderoni, Gasco, } \\
\text { \& Mauro, 2008; } \\
\text { Dianzani et al., } \\
2006 \text { ) }\end{array}$ \\
\hline
\end{tabular}

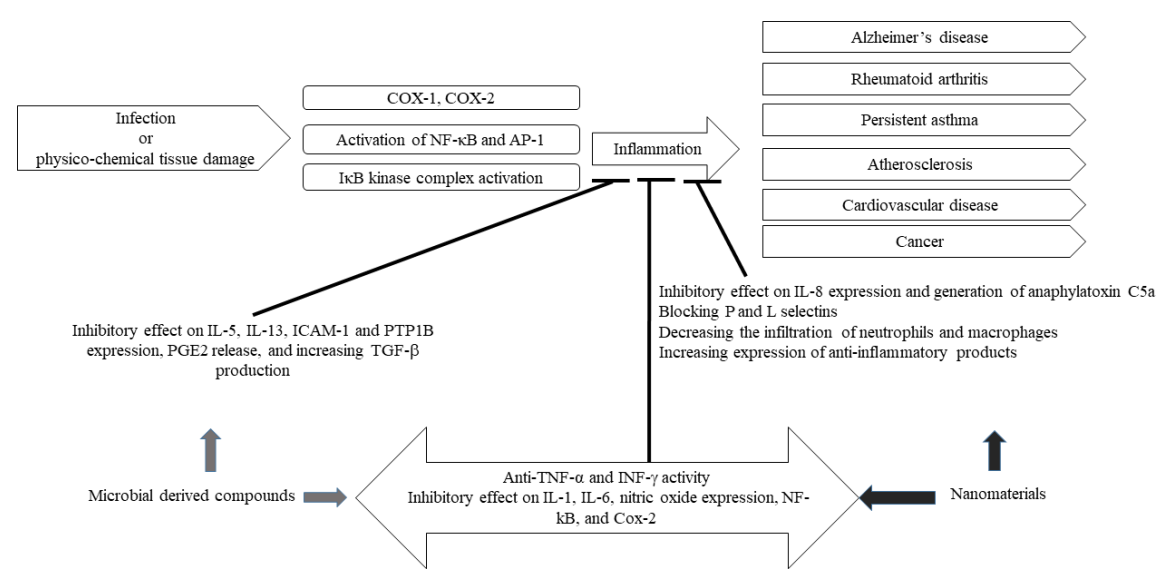




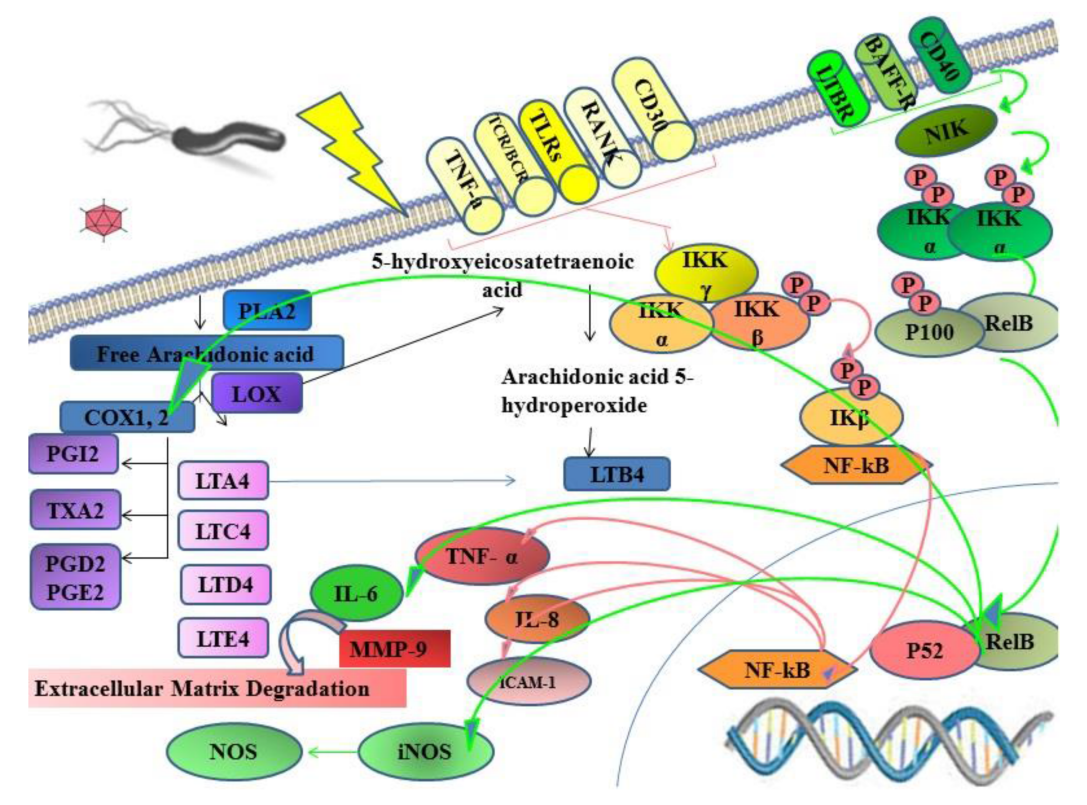

